Portland State University

PDXScholar

$11-4-2009$

\title{
Biological Control of Purple Loosestrife (Lythrum salicaria): Factors Affecting Galerucella pusilla and Galerucella calmariensis Establishment in Tidal Areas
}

Lynda Kathryn Moore

Portland State University

Follow this and additional works at: https://pdxscholar.library.pdx.edu/open_access_etds

Part of the Environmental Sciences Commons, and the Plant Sciences Commons Let us know how access to this document benefits you.

\section{Recommended Citation}

Moore, Lynda Kathryn, "Biological Control of Purple Loosestrife (Lythrum salicaria): Factors Affecting Galerucella pusilla and Galerucella calmariensis Establishment in Tidal Areas" (2009). Dissertations and Theses. Paper 3580.

https://doi.org/10.15760/etd.5464

This Thesis is brought to you for free and open access. It has been accepted for inclusion in Dissertations and Theses by an authorized administrator of PDXScholar. Please contact us if we can make this document more accessible: pdxscholar@pdx.edu. 
BIOLOGICAL CONTROL OF PURPLE LOOSESTRIFE (LYTHRUM SALICARIA):

FACTORS AFFECTING GALERUCELLA PUSILLA

AND GALERUCELLA CALMARIENSIS ESTABLISHMENT IN TIDAL AREAS

by

LYNDA KATHRYN MOORE

A thesis submitted in partial fulfillment of the requirements for the degree of

\author{
MASTER OF SCIENCE \\ in \\ ENVIRONMENTAL SCIENCES AND RESOURCES
}

PORTLAND STATE UNIVERSITY

2009 


\section{THESIS APPROVAL}

The abstract and thesis of Lynda Kathryn Moore for the Master of Science in

Environmental Sciences and Resources were presented November 4, 2009, and accepted by the thesis committee and the department.

COMMITTEE APPROVALS:

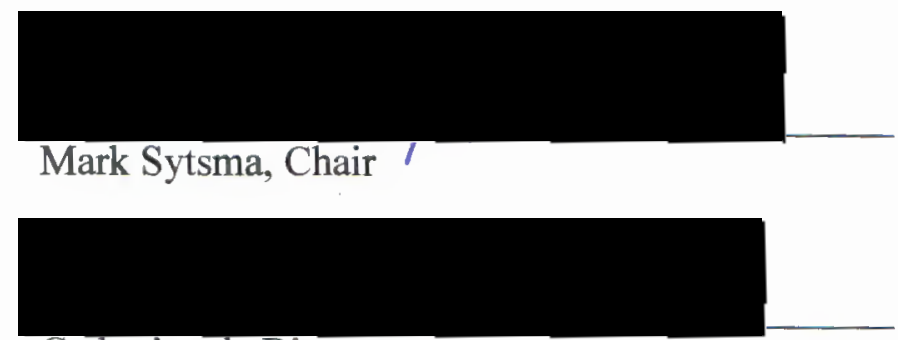

Catherine de Rivera

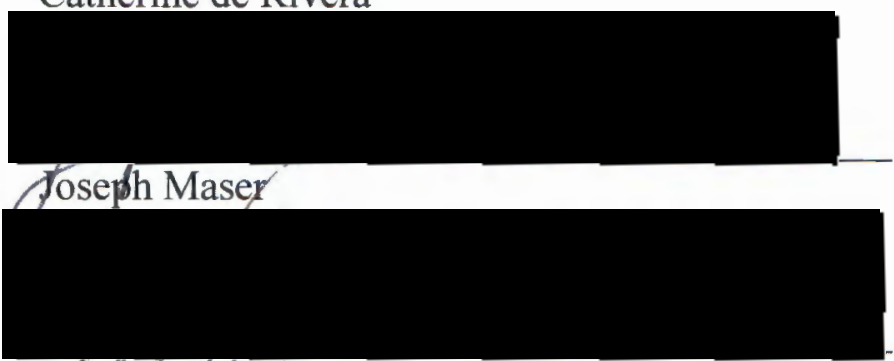

Eric M. Crombs

DEPARTMENT APPROVAL:

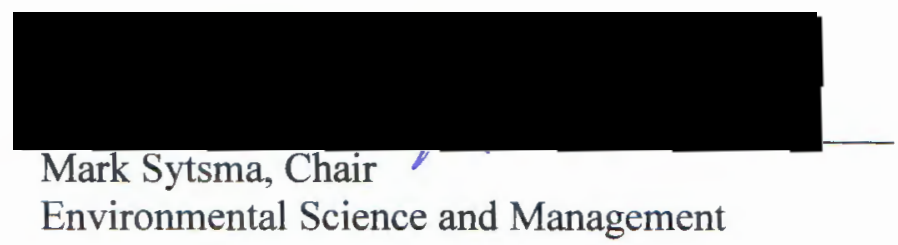




\begin{abstract}
An abstract of the thesis of Lynda Kathryn Moore for the Master of Science in Environmental Sciences and Resources presented November 4, 2009.
\end{abstract}

Title: Biological control of purple loosestrife (Lythrum salicaria): Factors affecting Galerucella pusilla and Galerucella calmariensis establishment in tidal areas

Galerucella pusilla and G. calmariensis have provided successful biological control of purple loosestrife (Lythrum salicaria L.) in non-tidal areas but only marginal control in areas of tidal influence. While a previous study identified mechanical scour by tidal waters as the main cause of establishment failure, purple loosestrife stem density explained more than $80 \%$ of the variability in presence and absence of Galerucella at my study sites in the Columbia River Estuary. A logistic regression model using purple loosestrife stem density, elevation, and their interaction as predictors accurately predicted $92.5 \%$ of Galerucella presence or absence observations of a test dataset $(n=201)$. Field data also identified a critical threshold of approximately 32 purple loosestrife stems $/ \mathrm{m}^{2}$, above which Galerucella were present $100 \%$ of the time at the release sites.

In an effort to assist site selection for future purple loosestrife biological control releases in tidally influenced areas, I used field variables to build a logistic model to identify the factor(s) having the greatest influence on Galerucella presence. I then conducted a greenhouse study to identify mechanisms by which this factor affected the retention of Galerucella within the system. I subjected adult Galerucella 
pusilla to treatments of varying purple loosestrife stem densities and water velocities. Results showed that the greatest proportion of Galerucella scour occurred at low stem density and scour was reduced by $16 \%$ with increased stem density. Contrary to previous understanding, both water velocity and stem density had an effect on Galerucella scour. Basic pre-release site knowledge including purple loosestrife stem density and elevation can greatly improve the establishment of purple loosestrife biological control programs in tidal areas. 


\section{Dedication}

To any who fear they are not capable or worthy of a graduate degree: You can do this, and you are most definitely worthy.

"The human race is challenged more than ever before to demonstrate our mastery - not over nature but of ourselves" 


\section{Acknowledgements}

I am indebted to many, including but not limited to: My committee members for guidance and expertise; my statistics group including Zoe Rodriguez del Rey and Sarah Freed (without whom I would still be staring at my field data); Zoe also provided tremendous help with GIS; my lab mates in the Center for Lakes and Reservoirs and the Aquatic Bioinvasion Research and Policy Institute; the many who helped with field work including Rachael Charles, Maimai Coats, Shorma Crawford, Katie Fehring, Elise Ferrarese, Rebecca Hill, Erin Miller, Erin Thompson, and Carson Wille; Head Pirate, Ralph Garono, for humor and mentorship; my mom, Susan Moore, a consummate model of 'Stubborn Like Bull' when it comes to attaining a goal; my dad, Bob Moore, for consistent interest and encouragement, even if he didn't understand "what the hell I was doing"; my Pod- you know who you are- for patience, love, and reality checks; anyone for whom my memory fails - Thank You!

Funding for this project was provided in part by The U. S. Army Corps of Engineers through a grant provided to Earth Design Consultants, Inc., the Center for Lakes and Reservoirs at Portland State University, and Marion Dresner through a Research Assistantship. I sincerely thank you all.

None of this would have been possible were it not for the basal support, belief, and propping up provided to me by Mai K. Coats. You have my undying appreciation, admiration, and love. You get a huge party now. And then I will sleep. 


\section{Table of Contents}

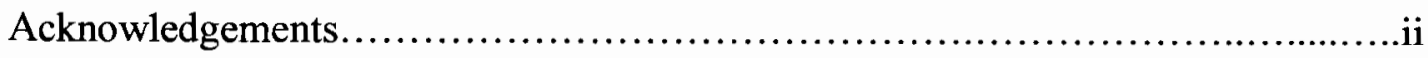

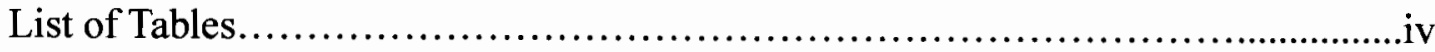

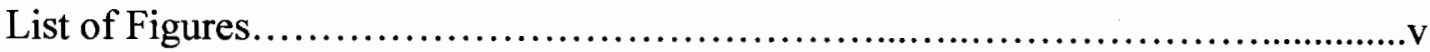

Introduction.............................................................................

Methods

Field Data Collection........................................................11

Field Data Analysis.....................................................17

Greenhouse Experiment Data Collection..................................18

Greenhouse Experiment Data Analysis.....................................25

Results

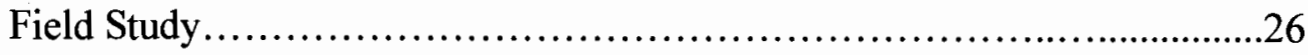

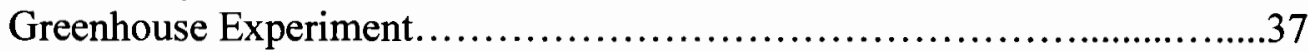

Discussion

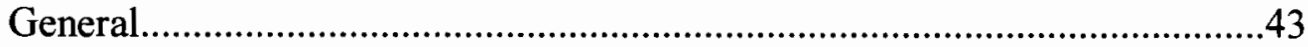

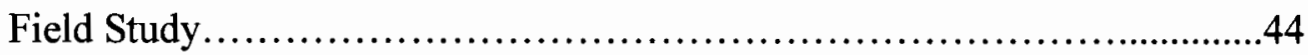

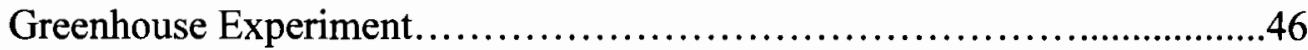

Management Implications.............................................5

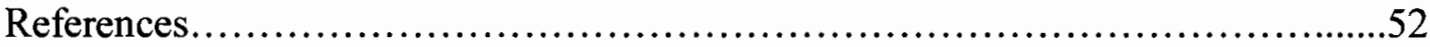

Appendix A

Specifications and images of greenhouse experimental apparatus.............57 


\section{List of Tables}

Table 1. Approximate Columbia River Mile (CRM) and spatial coordinates of each biological control agent release site (NAD83 Conus)....................................11

Table 2. Elevation gradient sampled, inundation depths and flood velocities experienced at release sites. Inundation and velocity data represent April - July, 2008 (Garono et al. 2008).

Table 3 Variables measured in the field at three sites within the Columbia River Estuary.

Table 4 . Three by three random block experimental design. $\mathrm{H}=$ Horizontal water velocity $(\mathrm{cm} / \mathrm{min}), \mathrm{V}=$ vertical water velocity $(\mathrm{cm} / \mathrm{min})$, number represents replicates

Table 5. Variables measured during greenhouse experiment subjecting Galerucella adults to treatments of varying stem densities and water velocities.

Table 6. Plants observed at Columbia River Estuary study sites. (Percent cover rank $(1=$ dominant $) /$ number of quadrats within which plant was observed $)$.

Table 7. Summary of logistic regression model predicting Galerucella presence/absence using elevation (m) and purple loosestrife stem density as predictors. Final model including interaction term (top) compared to alternative model which did not include interaction (bottom)

Table 8. Effects of different factors and their interactions on the number of Galerucella scoured during greenhouse experiment. 


\section{List of Figures}

Figure 1. The expected patterns of Galerucella scour relative to purple loosestrife stem density and water velocities

Figure 2. Location of the three study sites in the Columbia River Estuary between Columbia River Mile 39 (Tenasillahe) and 53 (Eureka).

Figure 3. Three stem density treatments randomly assigned to six-celled floral blocks. High treatment (30) (left), Medium (15) (center), and Low (5) (right). .21

Figure 4. Three-dimension representation of experimental apparatus showing flowthrough inner chamber contained within larger plexiglass box. (3D rendering courtesy of Graham Stephens).

Figure 5. Experimental apparatus used in greenhouse study to investigate the effects of purple loosestrife stem density and water velocity on scour of Galerucella. Arrows depict flow of water. (Line drawing courtesy of SageWarner).

Figure 6. Relationship of Galerucella abundance to elevation and purple loosestrife stem density. Purple loosestrife were rarely observed at low $(<1.75 \mathrm{~m})$ and high $(>$ $3.0 \mathrm{~m}$ ) elevations and there were correspondingly few Galerucella.

Figure 7. Graphical depiction of critical stem density of approximately 32 stems, below which Galerucella adults might be present or absent, above which Galerucella is always present.

Figure 8a. Points sampled at Dry Dock. Circles represent Galerucella occurrences; squares represent purple loosestrife occurrences, symbols being proportional to density. Base layer depicts elevation gradient as seen in LiDAR (Puget Sound LiDAR

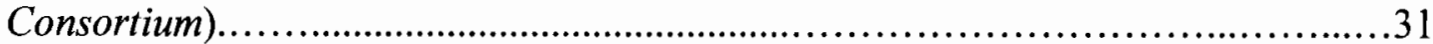

Figure 8b. Points sampled at Eureka. Circles represent Galerucella occurrences; squares represent purple loosestrife occurrences, symbols being proportional to density. Base layer depicts elevation gradient as seen in LiDAR (Puget Sound LiDAR Consortium).

Figure 8c. Points sampled at Tenasillahe. Circles represent Galerucella occurrences; squares represent purple loosestrife occurrences, symbols being proportional to density. Base layer depicts elevation gradient as seen in LiDAR (Puget Sound LiDAR Consortium).... 


\section{List of Figures Continued}

Figure 9. Logistic model performance. The solid line indicates the $50 \%$ probability used to categorize the data. The model correctly predicted $92.5 \%$ of the 201 Galerucella presence/absence observations in the test data. Ten false-positives (5\%, upper-left) and four false-negatives ( $2 \%$, lower-right) occurred.

Figure 10. Sampled Galerucella observations plotted against their latitude and longitude: Dry Dock top left, Eureka top right, Tenasillahe bottom left, and study site bottom right. The lack of spatial clumping validates there is no spatial autocorrelation, circles are proportional to number of Galerucella observed. .36

Figure 11. Aggregation of beetles on shoot tips as water continues to rise within experimental apparatus (top). Beetle at the center of the frame is investigating the rising water with its antennae (bottom).

Figure 12. Proportion of Galerucella scoured from the system ( $\pm 1 \mathrm{SE})$ during greenhouse experiment. Dashed white lines represent predicted pattern of Galerucella proportion that would become scoured from system.

Figure 13. Mean Galerucella response across treatments. "Remain" means to remain submerged under the water's surface for the duration of the treatment; "Fly" means flee the system by flying away; "Evade" means to climb to the tip of a tall stem, thereby evading the water; and "Scour" means to have been pulled off of the stem by the water and scoured from the system.

Figure 14. Measure of effect sizes of purple loosestrife stem density and water velocity treatments on proportion of Galerucella scoured from system (top).

Trendlines superimposed to show overall downward trend with regard to proportion of Galerucella scoured and stem density (bottom) (Error bars of $\pm 1 \mathrm{SE}$ have been removed for simplicity). Data shown are group means

Figure 15. Following being scoured from purple loosestrife stem by rising/flowing waters, Galerucella adults "swim" on water surface tension. 


\section{List of Figures Continued}

Figure 18. Vinyl tube attached to plumbing fitting in lower portion of end wall. Water is pumped from submerged pump through gate valve, into vinyl tube and through the fitting creating unidirectional flow. .58

Figure 19. Thick end wall of interior chamber with 5 rows of $8(n=40) 0.95 \mathrm{~cm}(3 / 8$ in) holes with $7.6 \mathrm{~cm}(3 \mathrm{in})$ vinyl tubes glued into each to create laminar flow. Three rows of $7(n=21) 1.27 \mathrm{~cm}(1 / 2$ in) holes were also drilled into wall to reduce water restriction (not shown)..... 


\section{Introduction}

Classical biological control has been employed since 1888 when the vedalia beetle (Rodolia cardinalis) was introduced into California from Australia in an effort to control cottony cushion scale (Icerya puchasi) (Luck 1990). By 2004 more than 350 species for biological control had been released against 133 target plant species in 70 different countries (Julien and Griffiths 1998). Benefits of biological control include little to no harmful residues left in the environment, favorable long term costbenefit ratios, and self-perpetuating systems of control.

Unfortunately, the credibility of biological control practices has been degraded over time due to the poor linkage between monitoring projects and the decision making process (Woodward et al. 1999). Only a few standardized monitoring protocols have been developed and even fewer funds are available for such projects. As a result, the decision making process is poorly linked with on-the-ground monitoring, leaving managers to hazard a best guess on a species by species basis. The lack of long-term mechanistic data regarding invasive weed effects on the composition and functioning of ecosystems (Blossey et al. 2001), and rising concern over the introduction of one non-native species to control another have also contributed to the degradation of trust for biological control programs.

Biological control relies on the introduction of one non-native species to control another and requires earnest attention. Plant-herbivore interactions such as those exploited by many biological control programs have the potential to experience host shifts. Host range expansion is the process by which a natural enemy shifts hosts in the absence of evolution (Agosta 2006). An early example of host range expansion 
in biological control is the cinnabar moth (Tyria jacobaeae), a control agent used against tansy ragwort (Senecio jacobaea). The native arrowleaf ragwort (Senecio triangularis) was not included in host-specificity tests prior to the moth's U. S. debut in 1959 , presumably in part because the target and native plants occur at different elevation ranges (Hitchcock and Cronquist 1973). At the time of testing, researchers were not able to anticipate that global temperatures would rise as a result of climate change, thus enabling the adult moths to survive better at higher elevations where the native arrowleaf ragwort and tansy ragwort occur (Sparks et al. 2006). As a result, the moth has been observed to occasionally attack the native species (Diehl and McEvoy 1990, Coombs et al. 2004). There have since been substantial scientific and regulatory improvements that decrease the probability of non-target impacts. One such improvement is the establishment of the Technical Advisory Group for Biological Control Agents of Weeds (TAG), established in 1987. Members of TAG provide a much needed conduit of information between USDA Animal and Plant Health Inspection Service (APHIS), researchers, and APHIS Plant Protection and Quarantine. While efforts to ensure the safety of biological control programs are substantial and genuine, the reality remains that we will never be able to anticipate all of the factors that influence population distributions.

Evolutionary shifts, host shifts that occur concurrently with evolution (Agosta 2006), are also a real concern with regard to biological control programs. Stenberg et al. (2008) showed repeated herbivory by the same insect taxa caused elevated defense chemicals in the host plant, rendering it less suitable to the insect. "Rent rise" was the 
term offered to describe the auto-response in the plant that forced the beetle, Galerucella tenella, to increase its utilization of an alternate host in an entirely different genus (Rubus) (Stenberg et al. 2008). Most biological control programs rely entirely on the repeated herbivory by either one or a small suite of insects. As such, it would be irresponsible to ignore the possibility of the occurrence of an evolutionary shift. A third possibility of host shifts offered by Janzen (1985) is ecological fitting. In this scenario, a species that has developed evolutionary traits in one habitat arrives in a new habitat and simply "fits", developing new associations and using new resources. Janzen noted, "As anyone knows who has suffered a setback in life, you don't have to be well- adapted to survive. You just have to survive."

Diligence regarding the safety of biological control programs is also warranted due to the fact that they take direct advantage of propagule pressure. For this study I refer to propagule pressure as it is understood by animal ecologists; the greater number of individuals in each release event (propagule size) and the greater number of discrete release events (propagule number), the greater the probability the biological control agent will become established (Lockwood et al. 2005). Demographic stochasticity can be reduced by increasing propagule size (Simberloff 2009); demonstrated by Grevstad's study (1999) in which she found that biological control agent (Galerucella calmariensis and G. pusilla) establishment increased with increased propagule size. Increased propagule number decreases the effect of environmental stochasticity (Simberloff 2009). Biological control practitioners attempt to ensure this propagule rain (Harper 1977) is a steady one, frequently 
augmenting initial releases with more and more release events containing greater and greater numbers of agents. For example, a collaborative effort between the Minnesota Department of Agriculture, University of Minnesota, and the Minnesota Natural Resource Department to control purple loosestrife (Lythrum salicaria) released 30,000 Galerucella adult beetles in 1995 , followed by 160,000 in 1996, followed yet again by close to $1,000,000$ in 1997 (Skinner 1998). Prudence is warranted with regard to biological control. The practice depends on increased propagule pressure and the concern of a host shift occurrence is ever present. Even with the most stringent screening processes there is potential the biological control agent may become a pest requiring management, rather than a tool with which we manage pests.

The Code of Best Practices for Classical Biological Control of Weeds (The Code) was adopted and ratified at the 1999 X International Symposium on Biological Control of Weeds (Balciunas and Coombs 2004). The Code is voluntary and identifies twelve professional standards to which practitioners should aspire. Of specific interest to this project is practice number eight of The Code: "Stop releases of ineffective agents, or when control is achieved". Honest evaluation of classical biological control programs requires post-release biological control agent monitoring efforts be as judicious as are efforts to initially identify and test them. Practitioners and scientists recognized early the need for monitoring (Huffaker and Kennett 1959, Schroeder 1983, Woodard et al. 1999, Blossey 1999), but for lack of funding and political will this need still exists (Fowler 2000, Simberloff et al. 2005).

Purple loosestrife (Lythrum salicaria L., Lythraceae) is an emergent perennial, 
native to Europe, that was introduced to the United States in the early 1800 's. Introductions occurred accidentally in ship ballast, on livestock and their bedding shipped from Europe for trade, and intentionally for medicinal purposes (Malecki et al. 1993). Mature plants achieve 2-3m in height (Thompson et al. 1987) and live 20 years or more (Anderson 1995). Plants are capable of producing 2.5 million seeds annually (Malecki et al. 1993), the seeds disperse via water and by adhering to animals and vehicles.

By the mid-1800's loosestrife was established along much of the northeastern seaboard of the United States and easily expanded through inland canals during the latter part of the nineteenth century. Blossey et al. (2001) reported that the plant occurred in 47 of the lower $48 \mathrm{U}$. S. states (Florida being the only exception) and nine of the ten Canadian provinces. Purple loosestrife is currently listed as a noxious weed in 25 states in the U. S. and is prohibited or otherwise regulated in 8 others (USDA 2009). Studies have shown the plant to reduce native plant diversity (Garbor et al. 1996, Weiher et al. 1996, Schooler et al. 2006), alter litter decomposition rates (Emery and Perry 1996) and sediment chemistry (Templer et al. 1998), and negatively impact salmonid species by causing variation in the native seasonal detrital supply to the basal food chain (Grout et al. 1997). Pemintel et al. (2005) estimated costs associated with purple loosestrife control efforts in the United States to be $\$ 45$ million per year.

Researchers and land managers recognized monotypic stands of purple loosestrife as problematic in the 1980 's and work to identify potential biological control agents began soon after. After extensive choice and no choice testing, three 
beetles were approved for release against the plant in 1992: a root-mining weevil, Hylobius transversovittatus Goeze (Coleoptera: Curculionidae); and two leaf-beetles, Galerucella pusilla Duftschmidt and G. calmariensis L. (Coleoptera: Chrysomelidae). A flower-feeding weevil, Nanophyes marmoratus Goeze (Coleoptera: Curculionidae), was approved two years later. Due to the ease with which they are reared, their durability when shipped, and gregarious nature (L. Moore, personal observation), the two Galerucella species have become the "darlings" of many biological control programs and are released with the greatest frequency and in the greatest numbers. Galerucella have been released into over 1500 wetlands in 33 states by state and federal agencies as well as citizen scientists including schools and private land owners (Blossey et al. 2001).

Colonization by Galerucella is strongly influenced by the effect of conspecifics. Grevtad and Herzig (1997) showed $86 \%$ of all beetles released in their experiment settled on purple loosestrife plants upon which they had previously placed conspecifics whose elytra had been glued to prevent fleeing. The fact that beetles attract beetles serves to enforce the importance of propagule pressure in biological control and in this project in particular. Practitioners can increase the likelihood the biological control agents becoming established by augmenting existing populations. As discussed above however, the aggregation of agents can elevate the possibility of a host shift occurring.

Furthermore, isolated pheromones emitted by males of both G. pusilla and $G$. calmariensis are identical (Bartelt et al. 2006). This is important for two immediate 
reasons: first, the mechanism by which interspecific confusion is avoided is not understood and second, pheromones of Galerucella nymphaeae, a native Galerucella that co-occurs with the two introduced species, have not been identified.

Studies have shown biological control of purple loosestrife is highly effective where water levels are fairly consistent (such as in fresh water lakes with little or no input) or where managers are able to manipulate water levels (such as irrigation canals and some lakes/ponds) (Blossey et al. 2001, Palmer 2007). Purple loosestrife biological control programs have reduced plant biomass by as much as $90 \%$ in nontidal regions of several U. S. states (Piper et al. 2004). The effectiveness of loosestrife biological control in tidally influenced areas is limited but the mechanisms by which are not fully understood (Denoth and Myers 2005, Garono et al. 2007 and 2008).

The biological control effort to manage purple loosestrife in the Columbia River Estuary of northwestern Oregon began in 1997. Releases of the agents were made by watershed councils, local, state, and federal agencies, conservation groups, and private entities in both Washington and Oregon. Between 1997 and 2006, approximately 81,700 loosestrife agents were released within the estuary; approximately $85 \%$ of those were the two Galerucella species (L. Moore, unpublished data). Accurate evaluation of the Columbia River Estuary purple loosestrife biological control program is not possible until we better understand the factors influencing agent establishment in tidal areas, issues best illuminated through monitoring. Without this information we have no way of complying with the edict of The Code: "Stop releases of ineffective agents, or when control is achieved". 
Adherence to The Code is imperative if we are to recognize the occurrence of host shifts early, identify unintended effects of increased propagule pressure that is inherent to biological control, and preserve the integrity of the discipline of biological control as a whole.

This project builds on a 2005 study in which scour was identified as the reason purple loosestrife biological control agents fail to establish in tidal waters (Denoth and Myers 2005). In their study, scour was affected by the movement of tidal water. In addition to water movement, I expect that the velocity at which tidal waters rise and flow, debris contained within tidal waters, the topography and bathymetry of a site, refugia provided by plants, and the disturbance frequency of tidal water can affect scour. For this project I concentrated on the effects of water velocity and purple loosestrife stem density.

I used field variables to build a logistic model to identify the factor(s) having the greatest influence on Galerucella presence. I then conducted a greenhouse study to identify mechanisms by which this factor affected the retention of Galerucella within the system. It is currently common for practitioners to focus their release efforts at areas of high elevation within a site. Elevations might be acquired through datasets such as Light Detection and Ranging (LiDAR) data or topographical maps but are often made once at the site by visual identification of areas of high ground. Without such data, objective selection of areas of greatest elevation is often hindered by the time, effort, and will required to reach the highest point. As a result, releases have been made at moderate to low elevations, a fact that could very well contribute to 
establishment failure of the biological control agents. The monitoring provided in this study elucidates the variable exerting the greatest influence on Galerucella establishment, a variable that can be more reliably measured than elevation.

Based on Denoth and Myers (2005), I anticipated the energy of the flowing water to dislodge the beetles from the plant stems. The expected effects of stem density and velocity are depicted in Figure 1. I hypothesized that tidal waters act as a vector of Galerucella and as such, the greatest proportion of Galerucella will become scoured when a) stem densities are lowest and b) water velocity is highest.

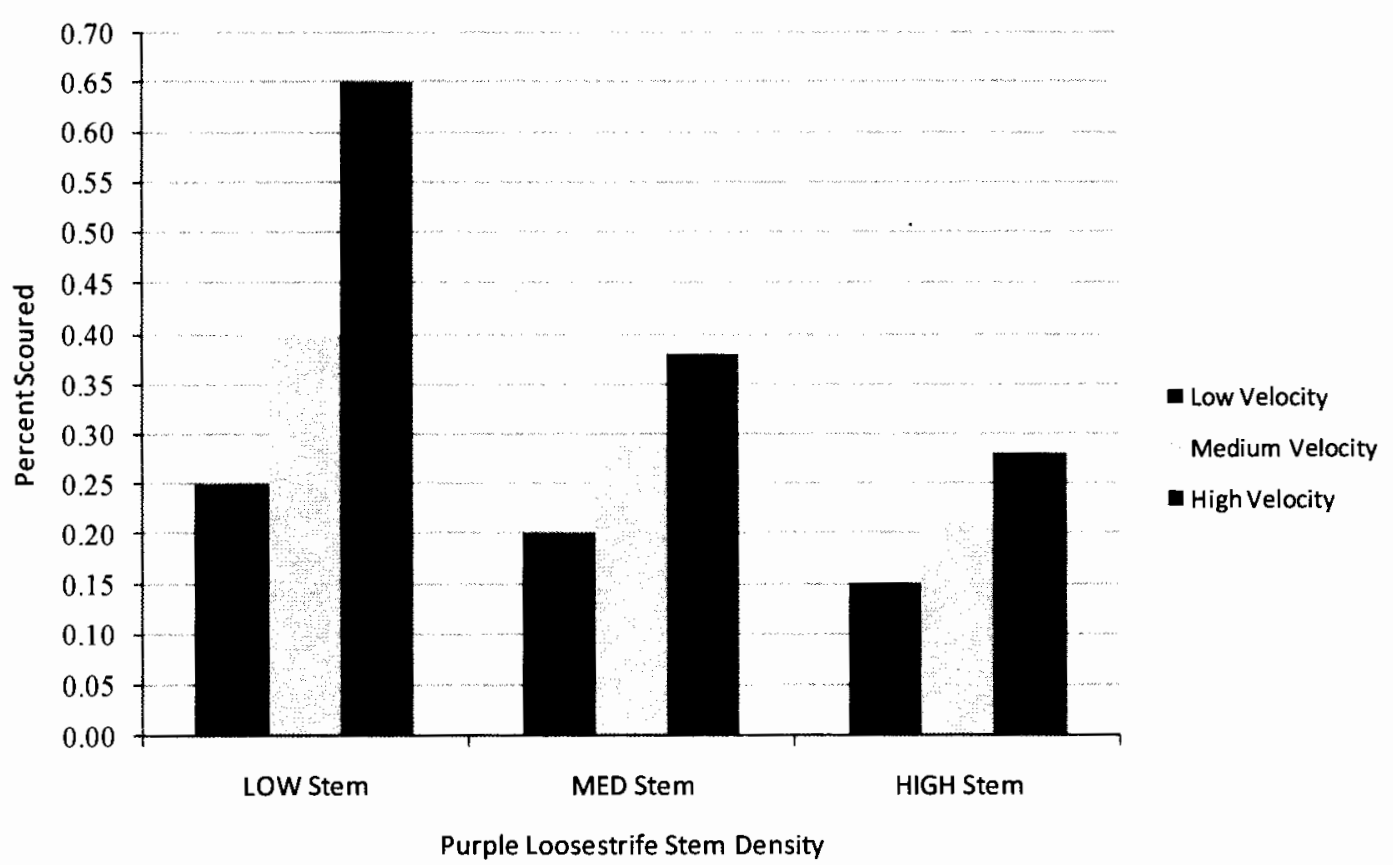

Figure 1. The expected patterns of Galerucella scour relative to purple loosestrife stem density and water velocities. 
The knowledge gained from this study will help strengthen the purple loosestrife biological control program by building a science-based link between monitoring and future site selection in tidally influenced areas. 


\section{Methods}

\section{Field Data Collection}

Three sites were selected within the Columbia River Estuary between

Columbia River Mile 39-53 (Table 1).

Table 1. Approximate Columbia River Mile (CRM) and spatial coordinates of each biological control agent release site (NAD83 Conus).

\begin{tabular}{llll}
\hline Site Name & CRM & Lat & Long \\
\hline Tenasillahe & 39 & $46.21506 \mathrm{~N}$ & $123.43797 \mathrm{~W}$ \\
Dry Dock & 41 & $46.20122 \mathrm{~N}$ & $123.44153 \mathrm{~W}$ \\
Eureka & 53 & $46.16054 \mathrm{~N}$ & $123.23057 \mathrm{~W}$
\end{tabular}

These sites represent a subset of a larger study assessing the establishment of purple loosestrife biological control agents, funded by the U. S. Army Corps of Engineers and implemented by Earth Design Consultants, Inc. of Corvallis, Oregon. The Tenasillahe site is located within a 101.2 ha, un-diked section of Tenasillahe Island (USFWS 2007), the Dry Dock site is near the location of the historic town of Bradwood on the Oregon mainland, and the Eureka site is located on the Eureka Complex, just northeast of Wallace Island (Figure 2). 


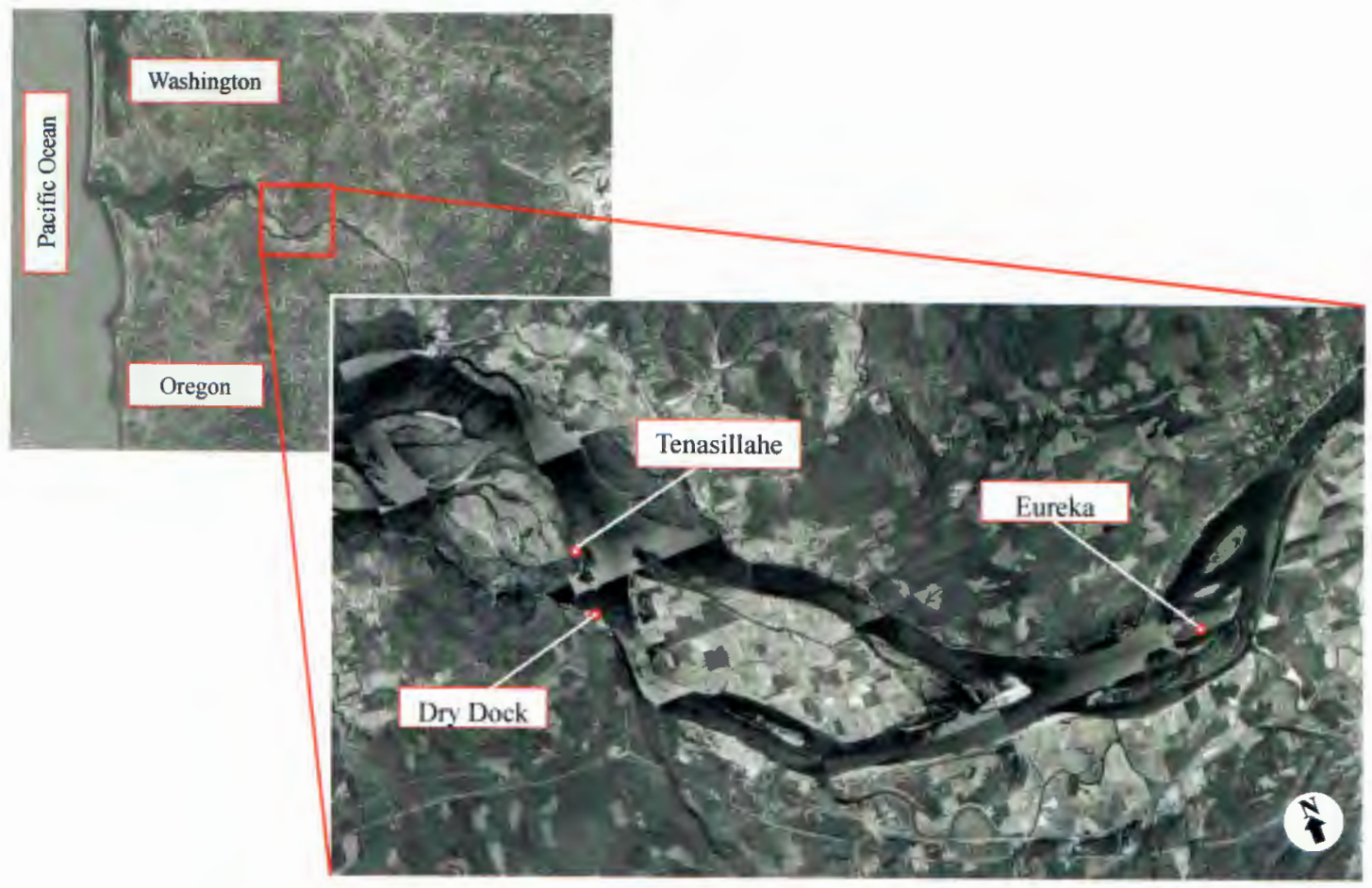

Figure 2. Location of the three study sites in the Columbia River Estuary between Columbia River Mile 39 (Tenasillahe) and 53 (Eureka).

All sites are typical inter-tidal swamps with native and non-native cattails (Typha spp.), wapato (Sagittaria latifolia Willd.), jewel-weed (Impatiens noli-tangere L.), common monkey-flower (Mimulus guttatus DC.), reed canary grass (Phalaris arundinacea L.), Carex spp., creeping spike-rush (Eleocharis palustris L.), willow (Salix spp.), etc. Black cottonwood (Populus balsamifera L. subsp. trichocarpa (Torr. \& Gray ) Brayshaw) and Sitka spruce (Picea sitchensis (Bong.) Carr.) occur at higher elevations.

My involvement with the larger project at 15 study sites in the Columbia River Estuary, including the three sites used in this study, afforded me a priori knowledge 
that purple loosestrife does not occur at all elevations represented at the sites. Cattails dominate at the lowest elevations and wind scour precludes purple loosestrife from growing at the highest, most exposed elevations. Therefore, I excluded the lowest and highest elevations occurring at each site, and sampled along an elevation gradient that would capture purple loosestrife occurrences. Elevation sampled among the sites range from $1.43-2.38 \mathrm{~m}(\mathrm{SD} \pm 0.39 \mathrm{~m})$ and tidal inundation depths at the sites range from $0.073-1.115 \mathrm{~m}$ (Table 2) (Garono et al. 2008).

Table 2. Elevation gradient sampled, inundation depths and flood velocities experienced at release sites. Inundation and velocity data represent April - July, 2008 (Garono et al. 2008).

\begin{tabular}{lllllllllll}
\hline & & \multicolumn{3}{c}{$\begin{array}{c}\text { Elevation of } \\
\text { Sampled Points (m) }\end{array}$} & \multicolumn{3}{c}{$\begin{array}{c}\text { Inundation Depths } \\
(\mathrm{cm})\end{array}$} & \multicolumn{3}{c}{$\begin{array}{c}\text { Flood Velocity } \\
\text { (cm/min) }\end{array}$} \\
\hline Site & $\mathrm{n}$ & Min & Max & Mean & Min & Max & Mean & Min & Max & Mean \\
\hline Dry Dock & 118 & 1.73 & 3.29 & 2.22 & 8.5 & 129.7 & 46.2 & 0.3 & 1.8 & 1.0 \\
Eureka & 127 & 2.38 & 3.19 & 2.72 & 7.3 & 115.5 & 41.8 & 0.3 & 1.7 & 0.8 \\
Tenasillahe & 157 & 1.43 & 2.86 & 2.06 & 12.7 & 149.3 & 58.1 & 0.3 & 1.7 & 1.0 \\
\hline
\end{tabular}

Purple loosestrife infestations range from dominant at Eureka $\left(\bar{x}=19.1 / \mathrm{m}^{2}\right)$ to sparse at Tenasillahe $\left(\bar{x}=3.1 / \mathrm{m}^{2}\right)$ with Dry Dock infestation levels between the two $\left(\bar{x}=3.3 / \mathrm{m}^{2}\right)$. Each site received 1,000 Galerucella adult beetles in July, 2005 in an effort to augment the previous purple loosestrife biological control efforts.

In order to identify elevation gradients and vegetative transition zones, I overlaid LiDAR data onto color infrared photographs of each site using ArcGIS (version 9.2). As the top-most layer, I utilized the free add-on software FISHNET, developed by Robert Nicholas (http://arcscripts.esri.com) to build a shapefile of a $5 \mathrm{X}$ 
$5 \mathrm{~m}$ systematic sampling grid of each site. I designed the study such that we would take measurements at a minimum of 100 points at each site, but the sampling grids were exaggerated to include a minimum of 250 sampling points per site. This cushion accommodated tidal inundation, vegetative barriers which were impossible to penetrate, inner channels, etc. yet included elevation gradients and plant community transitions.

I then uploaded the sampling grids to two handheld sub-meter GPS units (one Trimble GeoXH and one Trimble Recon with GPS Pathfinder Pro XRS field kit) from which members of two teams navigated to a pre-determined sampling point, measured variables within a $1 \mathrm{~m}^{2}$ quadrat, and then navigated to the next pre-determined sampling point. Measured response variables specific to the biological control agent (Galerucella) and environmental predictor variables are listed in Table 3. 
Table 3. Variables measured in the field at three sites within the Columbia River Estuary.

\section{Data Type Data Description}

\begin{tabular}{|c|c|c|}
\hline \multicolumn{3}{|l|}{ Predictor Variables } \\
\hline Date & Categorical & Date of field observation \\
\hline Column & Categorical & GIS column containing quadrat \\
\hline Row & Categorical & GIS row containing quadrat \\
\hline Elevation & Continuous & Elevation of quadrat (m) \\
\hline Latitude & Continuous & Latitude of quadrat \\
\hline Longitude & Continuous & Longitude of quadrat \\
\hline Stem & Continuous & $\begin{array}{l}\text { Number of live purple loosestrife stems } \\
\text { originating within quadrat }\end{array}$ \\
\hline \multicolumn{3}{|l|}{ Response Variables } \\
\hline GAPU Adult & Continuous & $\begin{array}{l}\text { Number of Galerucella pusilla adults } \\
\text { observed }\end{array}$ \\
\hline GACA Adult & Continuous & $\begin{array}{l}\text { Number of Galerucella calmariensis } \\
\text { adults observed }\end{array}$ \\
\hline GA Egg & Continuous & $\begin{array}{l}\text { Number of Galerucella egg masses } \\
\text { observed }\end{array}$ \\
\hline GA Larvae & Continuous & Number of Galerucella larvae observed \\
\hline NAMA Adult & Continuous & $\begin{array}{l}\text { Number of Nanophyes marmoratus adults } \\
\text { observed }\end{array}$ \\
\hline
\end{tabular}

Sampling continued in this manner until measurements had been collected from at least 100 sampling points at each site. The two teams started on opposite sides of the sampling grids so as to not disturb the environment prior to sampling.

Galerucella adults and larvae inflict damage to the purple loosestrife plants by feeding on the leaves, removing photosynthetic tissue. The larvae are by far the most damaging, frequently skeletonizing the plant, resulting in plant death or reduced shoot production the following year. Adults and larvae also feed on the flower buds which can stunt plants and reduce seed set.

According to Piper et al. (2004) and observed through personal observation in 
Oregon: Eggs of the European beetles are laid from approximately May to June by overwintering adults and August to September by new adults. Eggs occur in masses of 3-6, are barrel shaped, and are often topped with a bit of frass. There are three larval instar stages and development from eclosion to pupa is generally two weeks, depending on climatic conditions and food availability. Larvae pupate in the soil litter or in aerenchyma tissue if plant is in standing water. In northwestern Oregon, overwintering adults emerge mid-April and new adults emerge around July; a second generation of adults emerges in August. Adults are small (3-4mm in length) and golden in color, G. calmariensis having dark bands along its elytra.

Data were collected at each site during two distinct sampling periods to maximize probability of observing all life stages: 17 June-19 June and 30 July-2 August 2008. After the first sampling period, I re-evaluated the sampling locations to ensure the existent elevation gradients were properly represented. As a result, I added 20 points at Dry Dock and 25 at Eureka to the second sampling period. I added 41 new sampling points and removed 23 sampling points at Tenasillahe for a net gain of 18 points sampled during the second field visit. With the exception of the points mentioned above, the same locations were sampled during the second period as were sampled during the first. Our ability to navigate to the predetermined sampling point improved between the first and second surveys: $1.17 \mathrm{~m}( \pm 0.03 \mathrm{~m})$ difference between the predetermined and actual point on the first and $0.94 \mathrm{~m}( \pm 0.03 \mathrm{~m})$ on the second (Garono et al. 2008).

All elevations were extracted from LiDAR data collected in August of 2005 
and obtained from the Puget Sound LiDAR Consortium

(http://pugetsoundlidar.ess.washington.edu) and reference NAVD88 Datum. I used Bare Earth data to measure elevations at ground level rather than Top Surface data, which measure from the top-most surface of objects such as vegetation, buildings, etc. The resolution of the Bare Earth LiDAR was 6 X $6 \mathrm{ft} .(1.83 \times 1.83 \mathrm{~m})$. The spatial locations of each quadrat were differentially corrected referencing a base station at Raymond, Washington.

Field Data Analysis

The free software program ' $R$ ' (Version 2.8.1) was used for statistical analysis of the field data. Because Galerucella adults and the three larval instars are mobile, field teams could not be confident that an individual counted during the first period was different than one counted during the second period. For this reason, I used the mean across time for all data analysis with the resulting data set containing a total of 402 sample units (quadrats). As is the case with many ecological studies involving count data of rare species, the data were highly zero inflated. Therefore, I built the first component of a two-part, conditional model as recommended by Cunningham and Lindenmayer (2005). With this approach a logistic model is used to determine the factors influencing whether or not the species will be present, and then the abundance of the species, given it is present, is modeled using a Poisson distribution. Separating the models in this way allowed for the consideration that different processes may be affecting the two different components. 
To build a logistic model, I used a random stratified design in which $50 \%$ of the data points from each site were randomly selected (Dry Dock $n=59$, Eureka $n=64$ sites, and Tenasillahe $n=78$ points) and then pooled to make the larger data set ( $n=$ 201) upon which the model was built. The remaining $50 \%$ of the randomly stratified data (Dry Dock $n=59$, Eureka $n=63$, and Tenasillahe $n=79$ points) were reserved to validate the model $(n=201)$.

Two logistic models were developed using the number of live purple loosestrife stems and elevation as predictors of Galerucella presence; one model included an interaction term while the other did not. I selected the model that best fit the data, had significant slopes for the predictor variables, and explained the greatest amount of null deviance and used it to test the remaining half of the data. I conducted ANOVAs on the models to determine if there was a significant difference between them, as well as on each model to determine significance level to which each predictor explained residual deviance. In order to evaluate the goodness of fit I compared the deviance of the final model to the deviance of the null model. To check for spatial dependence I mapped the observations against their latitude and longitude and verified no spatial clustering existed.

\section{Greenhouse Experiment Data Collection}

Greenhouse studies were conducted at the Center for Lakes and Reservoirs greenhouse on the campus of Portland State University July 5-9, 2009. In a 3 X 3 randomized block design I subjected Galerucella pusilla adults to treatments of 
varying purple loosestrife stem densities and water velocities to measure the effects on the beetles becoming scoured from the system. Treatments were blocked by day in a randomized block design: every treatment was randomly assigned to each block (day) (Table 4). Field observations revealed greater frequency of egg masses than larvae and more larvae than adults. While the greatest mean Galerucella egg mass to mean purple loosestrife stem density ratio was 7.9 , the mean Galerucella adult to mean purple loosestrife stem density ratio was only 0.8 . However, reports of mean adult to stem density ratios as high as 4.9 have been reported in non-tidal areas (Lindgren 1999). I therefore selected to include two adults per stem and maintained this relative density across all treatments.

Table 4. Three by three random block experimental design. $\mathrm{H}=$ Horizontal water velocity $(\mathrm{cm} / \mathrm{min}), \mathrm{V}=$ vertical water velocity $(\mathrm{cm} / \mathrm{min})$, number represents replicates.

\begin{tabular}{llrrr}
\hline & \multicolumn{4}{c}{ Stem Density } \\
\hline & Low (5) & Medium (15) & High (30) \\
\hline & Medium $(\mathrm{H}=5.5, \mathrm{~V}=0.5)$ & 5 & 5 & 5 \\
& High $(\mathrm{H}=13.5, \mathrm{~V}=1.0)$ & 5 & 5 & 5 \\
& 5 & 5 & 5 & 5 \\
\hline
\end{tabular}

Galerucella pusilla adults were collected from an area in north Portland locally known as Pickle Pond $\left(45.617868^{\circ},-122.778728^{\circ}\right)$ on $4-8$ July, 2009. The insects were randomly sorted into groups of 10,30, and 60 each evening of collection, placed in polyethylene containers with fresh purple loosestrife plant material, and stored at 
room temperature until used the following day. At the termination of each run the individuals subjected to treatment were recollected, provided with fresh loosestrife plant material, and kept at room temperature until all blocks were complete. In this way new individuals were used for each treatment and all insects were returned to Pickle Pond only at the conclusion of the experiment.

Purple loosestrife stems to be used in the experiment were collected at the time of insect collections. In the greenhouse, I marked any stem $>4 \mathrm{~cm}$ in diameter at the base and used it as food for the insects. Stems $<4 \mathrm{~cm}$ in diameter were randomly selected for stem density treatments. The average mean $\mathrm{stem} / \mathrm{m}^{2}$ was 8.2 , with a maximum of $55 / \mathrm{m}^{2}$ in the field. The sample area used in this experiment was slightly larger than $0.25 \mathrm{~m}^{2}$. In an effort to include stem densities which exaggerated those observed in the field, I selected stem density treatments of 5,15 , or 30 . There was one tall $(33 \mathrm{~cm}$ from apical tip to cut) stem that reached above the highest water level in the low stem density treatment, two in the medium stem density treatment, and 3 in the high stem density treatment. All other stems were "short" $(23 \mathrm{~cm}$ from apical tip to cut). I used $35.5 \times 35.5 \mathrm{~cm}$ wire grids of $4 \times 4 \mathrm{~cm}$ cells as a substrate upon which to place floral foam blocks ( $7.6 \mathrm{~cm} \mathrm{X} 10 \mathrm{~cm} \mathrm{X} 23 \mathrm{~cm}$, Oasis), two blocks in the treatment of 5 and 15 each and three blocks in the treatment of 30 stems (Figure 3). I divided the floral foam blocks into a six-cell grid and used a random number generator to determine placement of stems within each treatment, no cell contained more than 2 stems. To keep the foam blocks from floating I secured the foam blocks to the wire grid with the plastic wrap prior to stem placement. Stems were replaced with fresh 
material of the same length when wilt or browning appeared.

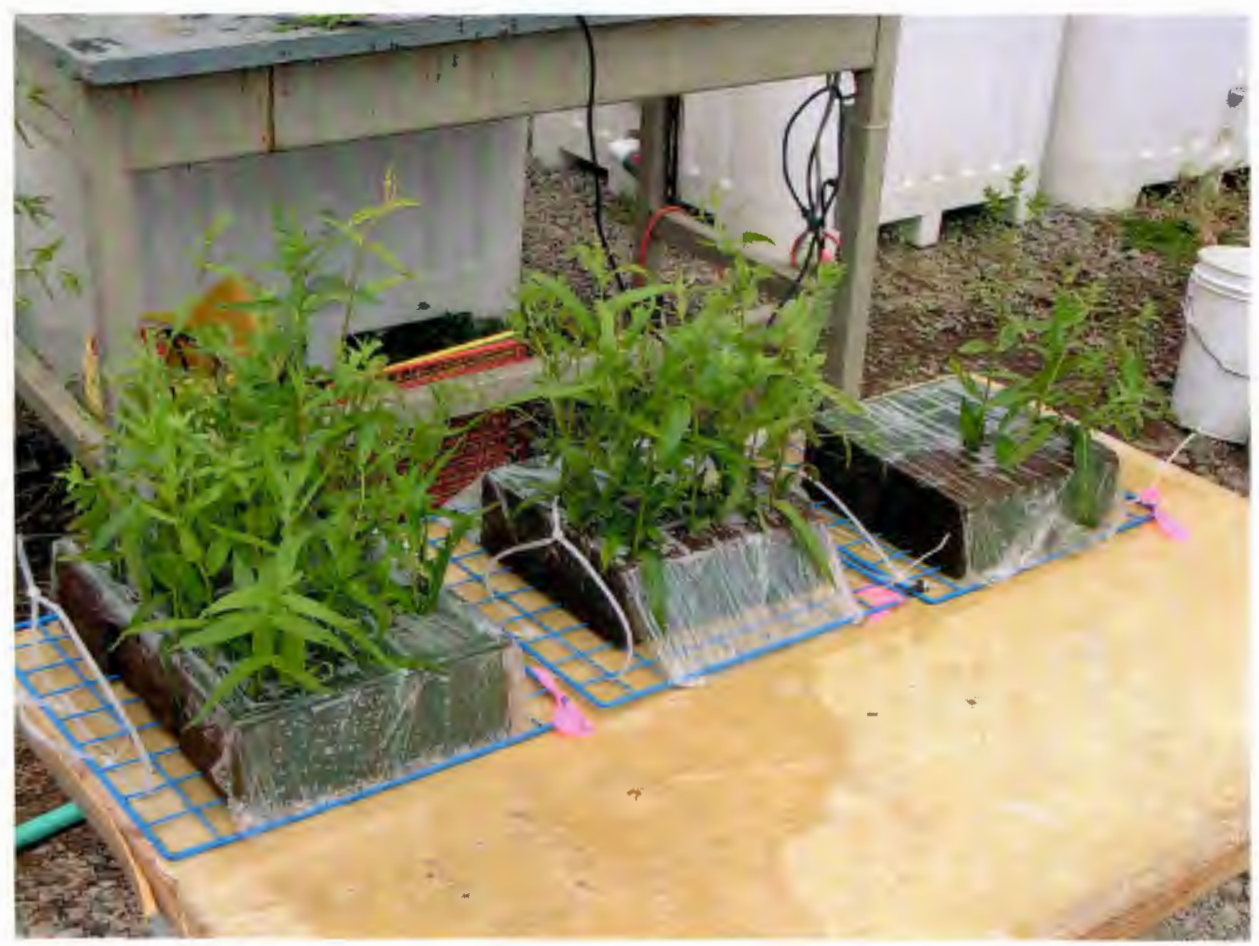

Figure 3. Three stem density treatments randomly assigned to six-celled floral blocks. High treatment (30) (left), Medium (15) (center), and Low (5) (right).

The experimental apparatus was a flow-through plexiglass chamber (approximate outer dimensions: $52 \mathrm{~cm} \mathrm{~L} \mathrm{X} 47 \mathrm{~cm} \mathrm{~W} \mathrm{X} 37 \mathrm{~cm} \mathrm{H}$ ) contained within a larger plexiglass box (approximate outer dimensions: $79 \mathrm{~cm} \mathrm{~L} \mathrm{X} 47 \mathrm{~cm} \mathrm{~W} \mathrm{X} 47 \mathrm{~cm} \mathrm{H}$ ) (Figure 4). All walls were $0.6 \mathrm{~cm}$ thick with the exception of one end wall of the interior chamber which was $0.95 \mathrm{~cm}$. Through this thicker plate I drilled five rows of eight $0.95 \mathrm{~cm}$ holes and glued into each a $7.6 \mathrm{~cm}$ vinyl tube to create laminar flow. In three alternating rows I also drilled seven $1.27 \mathrm{~cm}$ holes to reduce water restriction behind the end wall. 


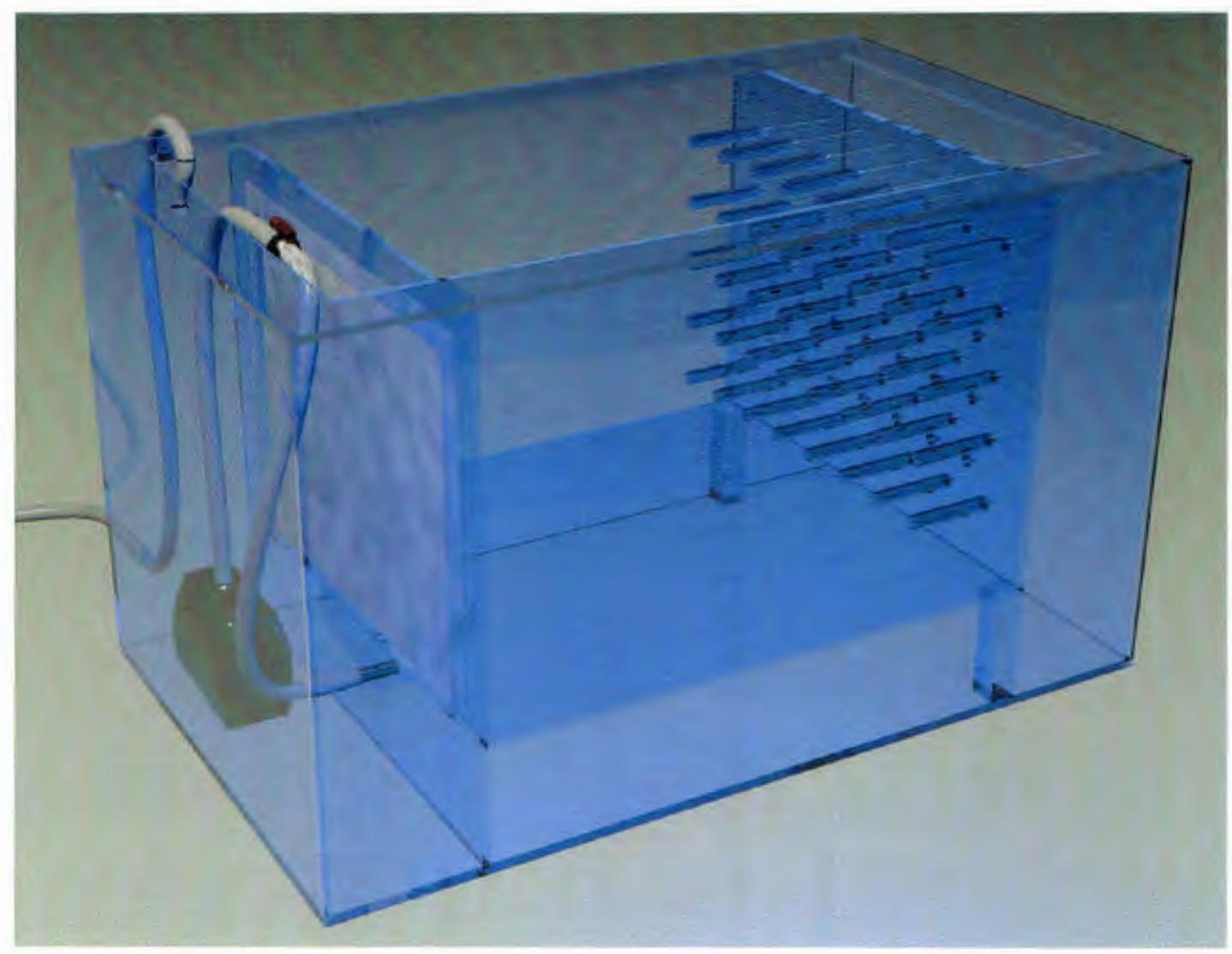

Figure 4. Three-dimension representation of experimental apparatus showing flowthrough inner chamber contained within larger plexiglass box. ( $3 D$ rendering courtesy of Graham Stephens)

De-chlorinated tap water was pumped through a vinyl tube from a large container to a ' $T$ ' junction. A PVC ball valve on one side of the ' $T$ ' diverted the water back to the large container, a ball valve on the other side of the ' $T$ ' diverted water to the experimental apparatus. After having calculated the un-constricted pump output and those of several different levels of constriction using the ball valve, I controlled the vertical water velocity by utilizing pre-determined marks on the valve. I used a smaller pump for the low vertical velocity treatment than for the medium and high treatments (GX2400 as opposed to GX6000, Gen-X). Again, having pre-measured the 
treatments (GX2400 as opposed to GX6000, Gen-X). Again, having pre-measured the output velocities at several settings, I manipulated the horizontal velocities similarly by running water from the apparatus through a submersible pump (GX2400, Gen-X), through a gate valve, and then uni-directionally through a fitting glued into a hole in one end wall of the apparatus. In order to account for the velocity slowing as the water level increased during filling, I decreased constriction (thereby increasing velocity) at pre-determined water levels to maintain an average velocity throughout the filling process. All water used during this experiment was run through a carbon filter and maintained at $15^{\circ} \mathrm{C}$ with a chiller (CW-500, Pacific Coast Imports).

Each run progressed as follows: I positioned the metal grate holding the appropriate number of stems on the bottom of the interior chamber nearest the thick end wall. I placed the corresponding number of beetles at the base of the purple loosestrife stems and allowed them to self-position on the plants for 15 minutes. Making sure the gate valve (horizontal velocity) was at the appropriate mark, I closed the ball valve diverting water to the large container, opened the ball valve directing water to the apparatus to the appropriate mark (vertical velocity), then supplied power to the pump within the apparatus. Water would flow from the large container into the apparatus and the pump would push water through the fitting in the wall in a unidirectional manner. As the outer box filled with water it would flow through the holes in the thick end wall (those with and without tubes) and fill the inner chamber. The water would rise and run at predictable velocities, flow through the no-see-um netting ( 525 holes per square inch) at the opposite end, and recycle through the pump 
(Figure 5). The short stems became completely submerged and the tall stems provided refugia from the water as the water level increased. At the termination of each block I drained and wiped the experimental apparatus clean. Specifications and photographs of the apparatus are provided in Appendix A.

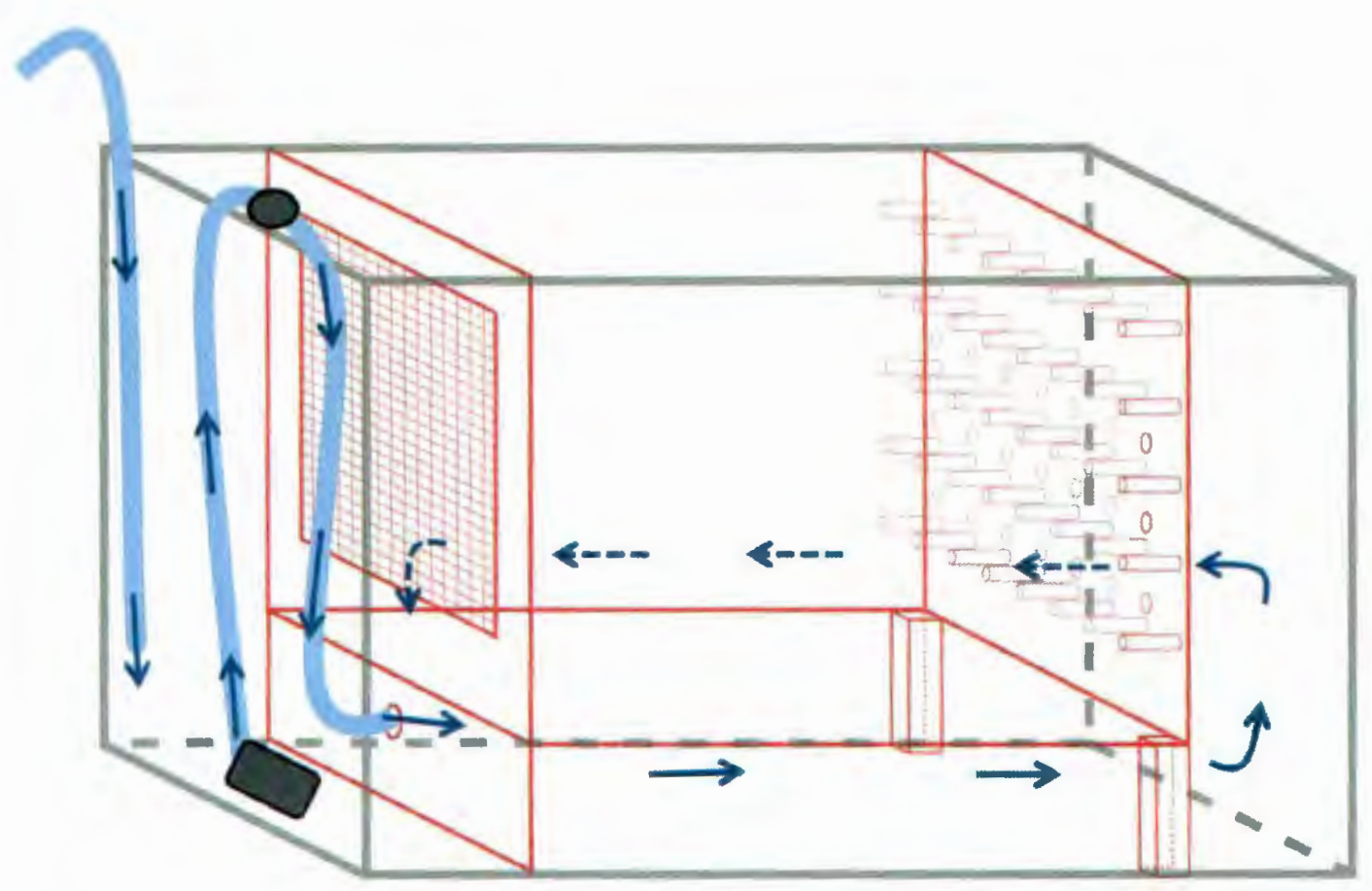

Figure 5. Experimental apparatus used in greenhouse study to investigate the effects of purple loosestrife stem density and water velocity on scour of Galerucella. Arrows depict flow of water. (Line drawing courtesy of Sage Warner) 
Greenhouse Experiment Data Analysis

Again the free software ' $R$ ' was utilized for the statistical analysis of greenhouse data (Version 2.9.2). Measured variables are provided in Table 5.

Table 5. Variables measured during greenhouse experiment subjecting Galerucella adults to treatments of varying stem densities and water velocities.

\begin{tabular}{|c|c|c|}
\hline & Data Type & Data Description \\
\hline \multicolumn{3}{|l|}{ Predictor Variables } \\
\hline Date & Categorical & Date of run \\
\hline Block & Categorical & Block number (blocked by date) \\
\hline Stem Density & Categorical & Number of purple loosestrife stems \\
\hline Run & Continuous & Run number \\
\hline Velocity & Categorical & Water velocity \\
\hline Max Temperature & Continuous & $\begin{array}{l}\text { Maximum temperature in greenhouse } \\
\text { during run }\end{array}$ \\
\hline Condition & Categorical & Climatic conditions during run \\
\hline \multicolumn{3}{|l|}{ Response Variables } \\
\hline Scour & Continuous & $\begin{array}{l}\text { Number of individuals pulled off of stems } \\
\text { and scoured from system }\end{array}$ \\
\hline Evade & Continuous & $\begin{array}{l}\text { Number of individuals that evaded water by } \\
\text { moving to tall stems }\end{array}$ \\
\hline Fly & Continuous & $\begin{array}{l}\text { Number of individuals that evaded water by } \\
\text { flying away }\end{array}$ \\
\hline Remain & Continuous & $\begin{array}{l}\text { Number of individuals that remained on } \\
\text { stem (under water) for duration of run }\end{array}$ \\
\hline
\end{tabular}

I used the logarithmic transformation $(x+1)$ in an effort to normalize the data and reduce patterns in the residuals. One point was identified as a potential outlier, but the calculated Cook's Distance was only 0.20 and therefore all data points were retained. I used a Two-way ANOVA to investigate the significance of treatment factors (alpha $=0.05)($ Gotelli and Ellison 2004). I also tested for interaction effects between the blocks and treatment factors using ANOVA. I conducted an a posteriori Tukey's HSD test to identify treatment levels that differed significantly (Zar 1996). 


\section{Results}

Field Study

Galerucella were observed in at least one life stage at elevations ranging from $1.88-$ $3.04 \mathrm{~m}(\mathrm{SD} \pm 0.24 \mathrm{~m})$ at three study sites within the Columbia River Estuary. The elevation range within which we observed purple loosestrife was $1.81-3.19 \mathrm{~m}$ (SD $\pm 0.27 \mathrm{~m})$. Galerucella were rarely observed at the low $(<1.75 \mathrm{~m})$ elevations and at higher elevations the density of beetles increased with increasing stem density. Purple loosestrife was sparse at some high elevations and there were correspondingly few Galerucella (Fig. 6). Table 6 provides a plant list and identifies the five most dominant plant species observed at each site. 


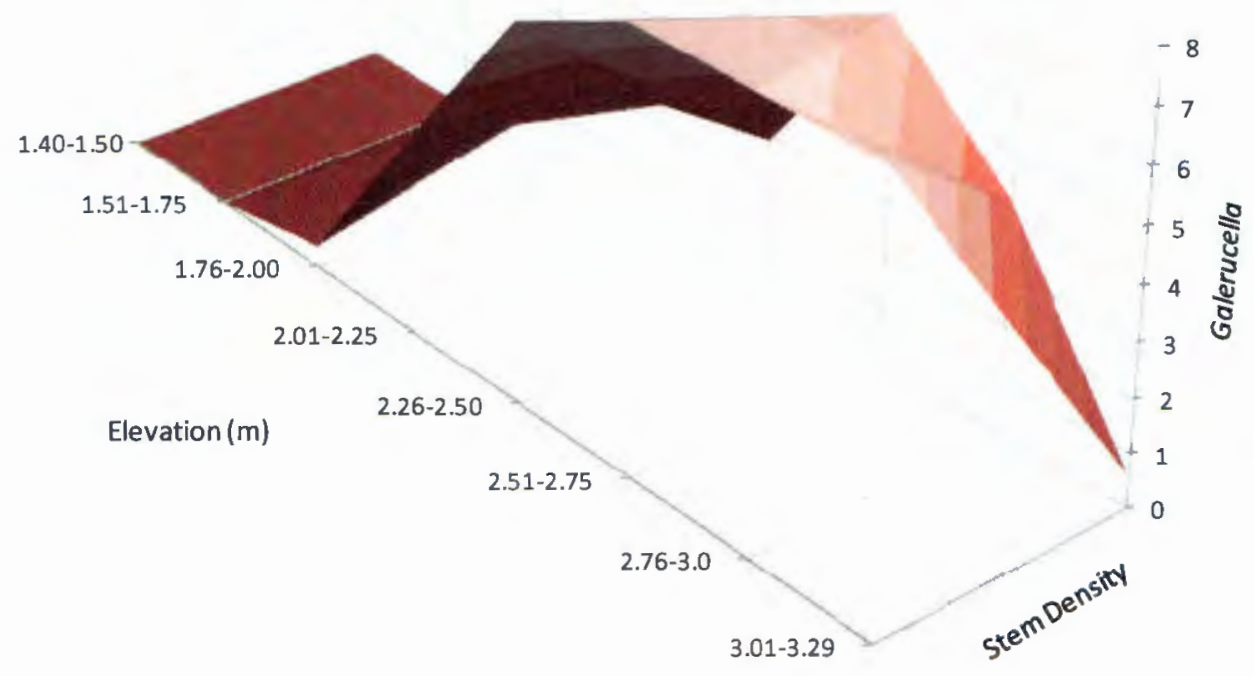

Figure 6. Relationship of Galerucella abundance to elevation and purple loosestrife stem density. Purple loosestrife were rarely observed at low $(<1.75 \mathrm{~m})$ and high (> $3.0 \mathrm{~m}$ ) elevations and there were correspondingly few Galerucella. 
Table 6. Plants observed at Columbia River Estuary study sites. Numbers in parentheses denote percent cover rank $(1=$ dominant $)$ /number of quadrats within which plant was observed.

\begin{tabular}{|c|c|c|c|c|}
\hline Botanical Name & Common Name & $\begin{array}{l}\text { Dry } \\
\text { Dock }\end{array}$ & Eureka & Tenas. \\
\hline Alisma trivial Pursh & Northern water-plantain & $\mathrm{X}$ & $\mathrm{X}$ & $\mathrm{X}$ \\
\hline Aster subspicatus Nees & Douglas' Aster & & & $\mathrm{X}$ \\
\hline Callitriche spp. & Water-starwort & $\mathrm{X}$ & $\begin{array}{l}X \\
(4 / 15)\end{array}$ & $\mathrm{X}$ \\
\hline Caltha leptosepala DC. & Marsh marigold & $\mathrm{X}$ & $\mathrm{X}$ & $X$ \\
\hline Carex spp. & Sedge & $X$ & $\mathrm{X}$ & $X$ \\
\hline Cirsium spp. & Thistle & $\mathrm{X}$ & $\mathrm{X}$ & \\
\hline Cornus sericea $\mathrm{L}$. & Creek dogwood & $\mathrm{X}$ & & $\mathrm{X}$ \\
\hline $\begin{array}{l}\text { Eleocharis palustris Roem. \& } \\
\text { Schult. }\end{array}$ & Creeping spike-rush & $\mathrm{X}$ & $\mathrm{X}$ & $\mathrm{X}$ \\
\hline Epilobium ciliatum Raf. & Purple-leaved willowherb & $\mathrm{X}$ & $\mathrm{X}$ & $\mathrm{X}$ \\
\hline $\begin{array}{l}\text { Epipactis gigantea Dougl. ex } \\
\text { Hook. }\end{array}$ & Stream orchid & & & $X$ \\
\hline Equisetum spp. & Horsetail & $\mathrm{X}$ & $\mathrm{X}$ & $\mathrm{X}$ \\
\hline Galium spp. & Bedstraw & $\mathrm{X}$ & $\mathrm{X}$ & $\mathrm{X}$ \\
\hline Helenium autumnale $\mathrm{L}$. & Common sneezeweed & & & $\mathrm{X}$ \\
\hline Impatiens noli-tangere $\mathrm{L}$. & Touch-me-not or Jewel-weed & $\mathrm{X}$ & & $\mathrm{X}$ \\
\hline Iris pseudoacorus $\mathbf{L}$. & Yellow-flag iris & $X$ & $\mathrm{X}$ & $X$ \\
\hline Juncus spp. & Rush & $X$ & $X$ & $\mathrm{X}$ \\
\hline Lemna minor $\mathrm{L}$. & Lesser duckweed & $\mathrm{X}$ & $\mathrm{X}$ & \\
\hline Lotus spp. & Trefoil & & $\mathrm{X}$ & $\mathrm{X}$ \\
\hline Lycopodium spp. & Club-moss & $\mathrm{X}$ & $\mathrm{X}$ & $X$ \\
\hline $\begin{array}{l}\text { Lysichiton americanum Hult. } \\
\& \text { St. John }\end{array}$ & Yellow skunk cabbage & $\mathrm{X}$ & & $\begin{array}{l}X \\
(5 / 12)\end{array}$ \\
\hline Lythrum salicaria $\mathrm{L}$. & Purple loosestrife & $\begin{array}{l}X \\
(2 / 45)\end{array}$ & $\begin{array}{l}X \\
(1 / 198)\end{array}$ & $\mathrm{X}$ \\
\hline Mentha spp. & Mint & $\begin{array}{l}X \\
(4 / 68)\end{array}$ & & \\
\hline Mimulus guttatus DC. & Common monkey-flower & & & $\begin{array}{l}X \\
(3 / 47)\end{array}$ \\
\hline Myosotis scorpioides L. & Common forget-me-not & $\begin{array}{l}X \\
(5 / 34)\end{array}$ & $\begin{array}{l}X \\
(3 / 51)\end{array}$ & $\mathrm{X}$ \\
\hline $\begin{array}{l}\text { Oenanthe sarmentosa Presl ex } \\
\text { DC. }\end{array}$ & Water parsley & $\mathrm{X}$ & & $X$ \\
\hline $\begin{array}{l}\text { Persicaria hydropiperoides } \\
\text { (Michx.) Small }\end{array}$ & Swamp smartweed & $\mathrm{X}$ & $\mathrm{X}$ & $\begin{array}{l}X \\
(4 / 27)\end{array}$ \\
\hline Phalaris arundinacea $\mathrm{L}$. & Reed canary grass & $\begin{array}{l}\mathrm{X} \\
(1 / 187)\end{array}$ & $\begin{array}{l}\mathrm{X} \\
(2 / 162)\end{array}$ & $\begin{array}{l}X \\
(1 / 140)\end{array}$ \\
\hline $\begin{array}{l}\text { Physocarpus capitatus (Pursh) } \\
\text { Ktze. }\end{array}$ & Ninebark & & & $\mathrm{X}$ \\
\hline Polygonum spp. & Polygonum & $\mathrm{X}$ & & $\mathrm{X}$ \\
\hline Potamogeton natans $\mathrm{L}$. & Common floating pondweed & $\mathrm{X}$ & & $\mathrm{X}$ \\
\hline Potentilla anserine $\mathbf{L}$. & Silver-weed & & & $\mathrm{X}$ \\
\hline Rosa spp. & Rose & $\mathrm{X}$ & & \\
\hline Rubus spp. & Blackberry & $\mathrm{X}$ & $\mathrm{X}$ & \\
\hline Rubus armeniacus $\mathrm{L}$. & Himalaya blackberry & & $\mathrm{X}$ & $\mathrm{X}$ \\
\hline
\end{tabular}


Table 6 Continued

\begin{tabular}{|c|c|c|c|c|}
\hline Botanical Name & Common Name & $\begin{array}{l}\text { Dry } \\
\text { Dock }\end{array}$ & Eureka & Tenas. \\
\hline Sagittaria latifolia Willd. & Wapato or Arrowhead & $\begin{array}{l}X \\
(3 / 65)\end{array}$ & $\mathrm{X}$ & $\begin{array}{l}X \\
(2 / 25)\end{array}$ \\
\hline Salix spp. & Willow & $\mathrm{X}$ & $\mathrm{X}$ & $X$ \\
\hline Scirpus spp. & Bullrush & $X$ & $\mathrm{X}$ & $\mathrm{X}$ \\
\hline Senecio jacobaea $\mathrm{L}$. & Tansy ragwort & $X$ & & \\
\hline Sium suave Walt. & Hemlock water-parsnip & $\mathrm{X}$ & & $\mathrm{x}$ \\
\hline Solanum dulcamara L. & Bittersweet nightshade & & $\mathrm{X}$ & \\
\hline Solidago canadensis L. & Canada goldenrod & $X$ & & \\
\hline Sium suave Walt. & Hemlock water-parsnip & $X$ & & $\mathrm{X}$ \\
\hline Solanum dulcamara $\mathrm{L}$. & Bittersweet nightshade & & $\mathrm{X}$ & \\
\hline Solidago canadensis $\mathrm{L}$. & Canada goldenrod & $X$ & & \\
\hline Typha spp. & Cattail & $\mathrm{X}$ & & $\mathrm{X}$ \\
\hline Unkown Apiaceae & & & $\begin{array}{l}X \\
(5 / 3)\end{array}$ & \\
\hline Vicia spp. & Vetch & $\mathrm{X}$ & & \\
\hline
\end{tabular}

There was a strong linear correlation between beetle abundance and purple loosestife stem density (Spearman's $\rho=0.84$ ). Beetles were present $100 \%$ of the time when purple loosestrife stem abundance was $32 \mathrm{stems} / \mathrm{m}^{2}$ or greater. Evidence of Galerucella varied at abundances less than $32 \mathrm{stems} / \mathrm{m}^{2}$ (Figure 6). 


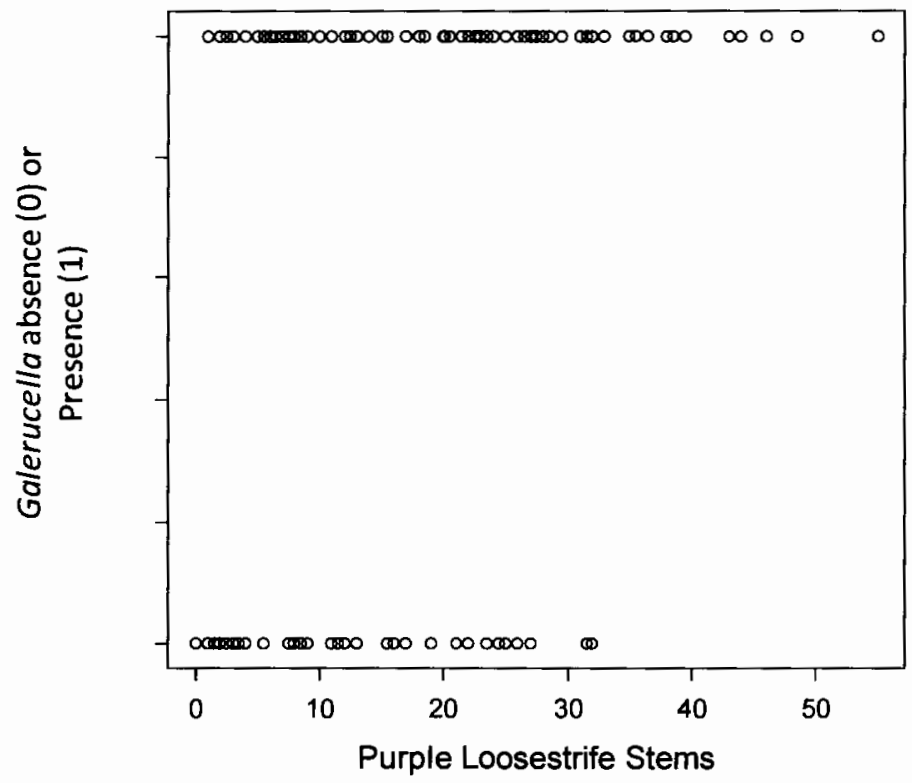

Figure 7. Graphical depiction of critical stem density of approximately 32 stems, below which Galerucella adults might be present or absent, above which Galerucella is always present.

Analysis utilizing GIS provided graphical representation of the co-occurrence of Galerucella with loosestrife plants, the exception being in areas experiencing high disturbance such as channels (Figure 8). 
Galerucella and Purple Loosestrife Observations (mean across time) Dry Dock 2008

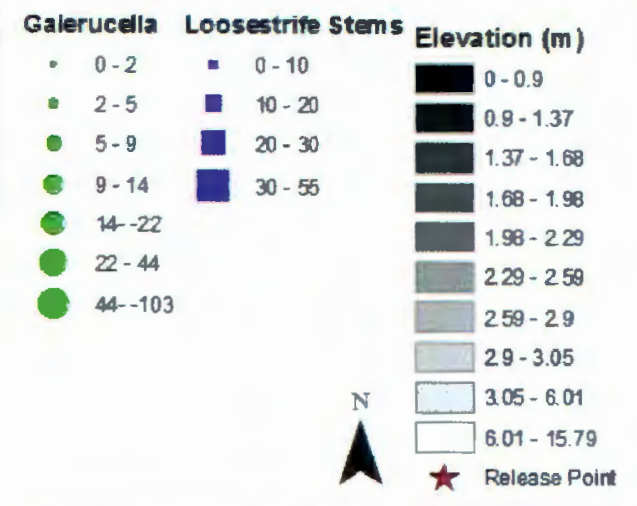

Figure 8a. Points sampled at Dry Dock. Circles represent Galerucella occurrences; squares represent purple loosestrife occurrences, symbols being proportional to density. Base layer depicts elevation gradient as seen in LiDAR (Puget Sound LiDAR Consortium). 


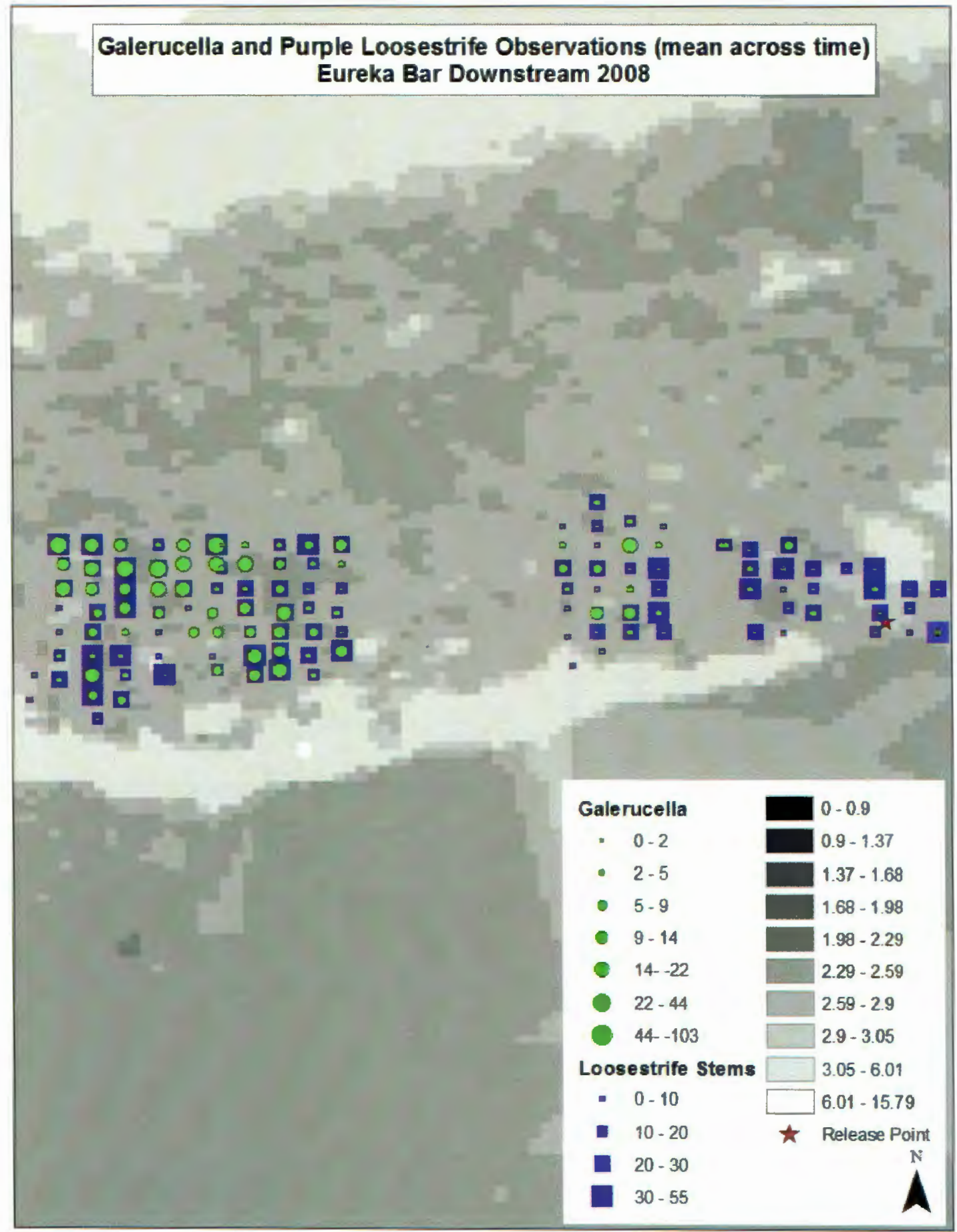

Figure 8b. Points sampled at Eureka. Circles represent Galerucella occurrences; squares represent purple loosestrife occurrences, symbols being proportional to density. Base layer depicts elevation gradient as seen in LiDAR (Puget Sound LiDAR Consortium). 


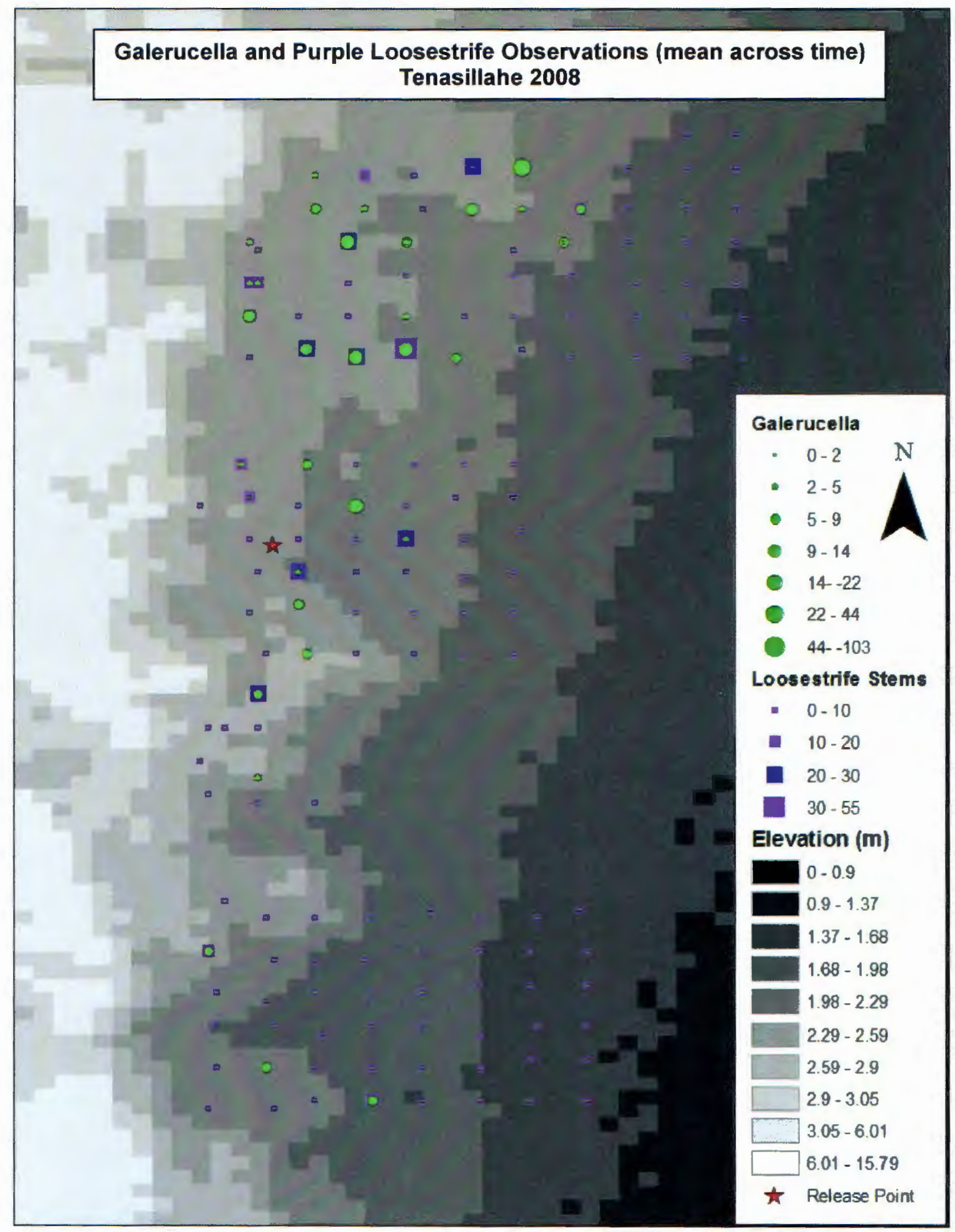

Figure 8c. Points sampled at Tenasillahe. Circles represent Galerucella occurrences; squares represent purple loosestrife occurrences, symbols being proportional to density. Base layer depicts elevation gradient as seen in LiDAR (Puget Sound LiDAR Consortium). 
The selected model included purple loosestrife stem density, elevation, and their interaction as predictors. The final model correctly predicted $92.5 \%$ of the present/absent observations of the test data $(n=201)$. False-positives occurred $5 \%(n$ $=10)$ of the time and false-negatives $2 \%(n=4)$ (Figure 9).

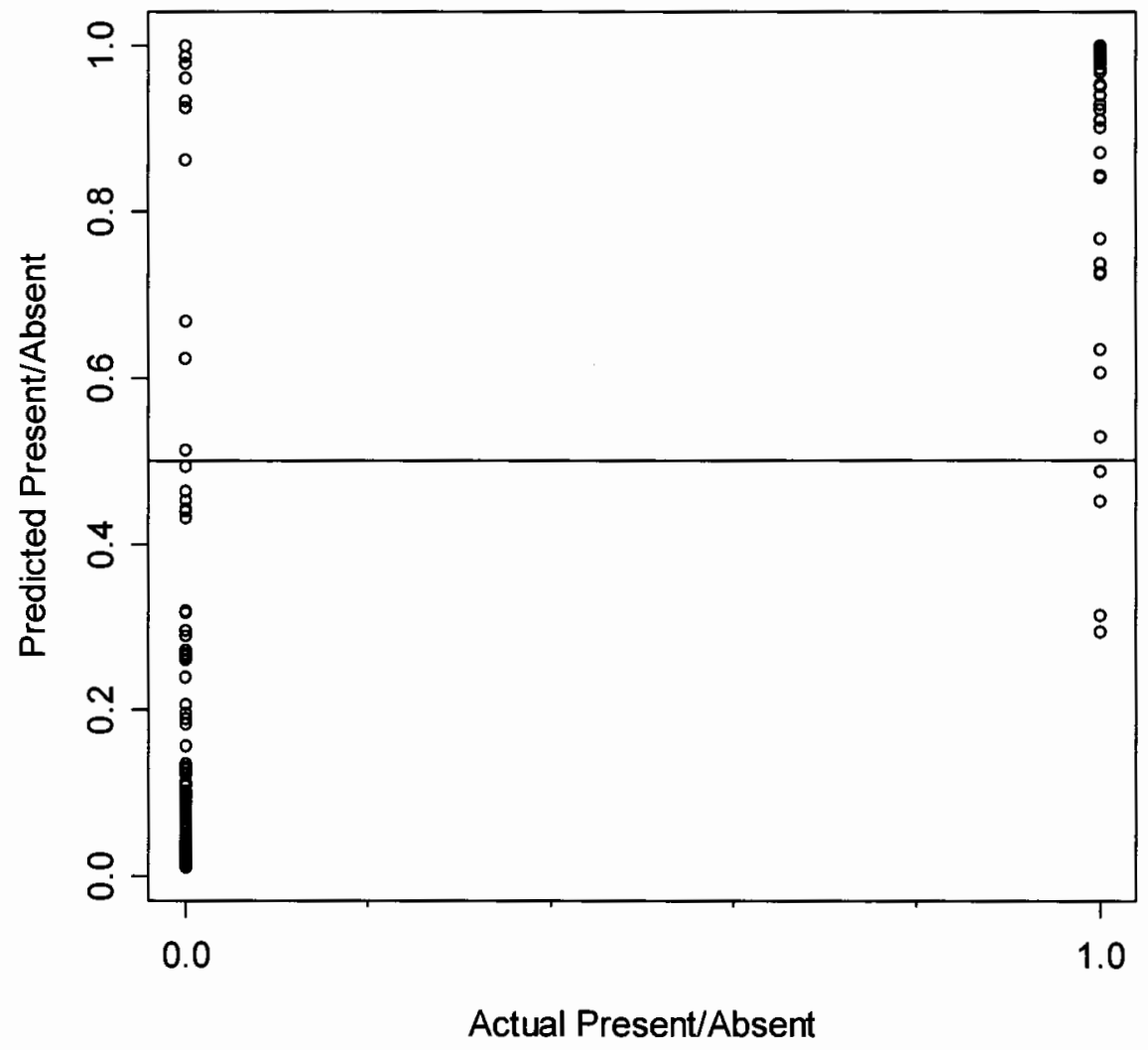

Figure 9. Logistic model performance. The solid line indicates the $50 \%$ probability used to categorize the data. The model correctly predicted $92.5 \%$ of the 201 Galerucella presence/absence observations in the test data. Ten false-positives (5\%, upper-left) and four false-negatives ( $2 \%$, lower-right) occurred. 
One-way ANOVA showed this model was significantly different than the model without the interaction term $\left(\mathrm{p}=2.57 \times 10^{-6}\right)$, had lower residual deviance than the null model, and lower residual deviance and AIC value than the model lacking the interaction term (Table 7).

Table 7. Summary of logistic regression model predicting Galerucella presence/absence using elevation $(\mathrm{m})$ and purple loosestrife stem density as predictors. Final model including interaction term (top) compared to alternative model which did not include interaction (bottom).

\begin{tabular}{|c|c|c|c|c|}
\hline & Estimate & $\begin{array}{l}\text { Std. } \\
\text { Error }\end{array}$ & $\mathrm{z}$ value & $\operatorname{Pr}(>|z|)$ \\
\hline Intercept & -8.0447 & 2.1495 & -3.743 & $0.000182^{* * *}$ \\
\hline Elevation & 2.4587 & 0.8751 & 2.810 & $0.004960^{* *}$ \\
\hline Stems & 2.1391 & 0.4204 & 5.089 & $3.60 \times 10^{-7} * * *$ \\
\hline Elevation:Stems & -0.6934 & 0.1435 & -4.832 & $1.35 \times 10^{-6 * * *}$ \\
\hline \multicolumn{5}{|c|}{$\begin{array}{l}\text { Null deviance: } 275.01 \text { on } 200 \mathrm{df} \text {, Residual deviance: } 108.81 \text { on } 197 \mathrm{df} \text {; AIC } 116.81 \\
\text { Significance levels: '**' } 0.001,{ }^{\prime * * *} 0\end{array}$} \\
\hline & Estimate & $\begin{array}{l}\text { Std. } \\
\text { Error }\end{array}$ & $\mathrm{z}$ value & $\operatorname{Pr}(>|z|)$ \\
\hline Intercept & -4.84764 & 1.64689 & -2.944 & $0.00325^{* *}$ \\
\hline Elevation & 1.25106 & 0.71340 & 1.754 & 0.07949 • \\
\hline Stems & 0.27776 & 0.04767 & 5.827 & $5.66 \times 10^{-9} * * *$ \\
\hline \multicolumn{5}{|c|}{$\begin{array}{l}\text { Null deviance: } 275.01 \text { on } 200 \mathrm{df} \text {, Residual deviance: } 130.92 \text { on } 198 \mathrm{df} \text {; AIC } 136.92 \\
\text { Significance levels: }{ }^{\prime} \cdot{ }^{\prime} 0.1^{6 * *} 0.001,{ }^{\prime * *}{ }^{*} 0\end{array}$} \\
\hline
\end{tabular}

Each predictor variable of the final model was significant. Visual inspection of the observations plotted against their coordinates revealed no evidence of spatial autocorrelation either at the scale of individual sites or study system as a whole (Figure 10). The deviance of the final model follows a Chi-square distribution $\left(\chi^{2}=\right.$ $1.05)$. 

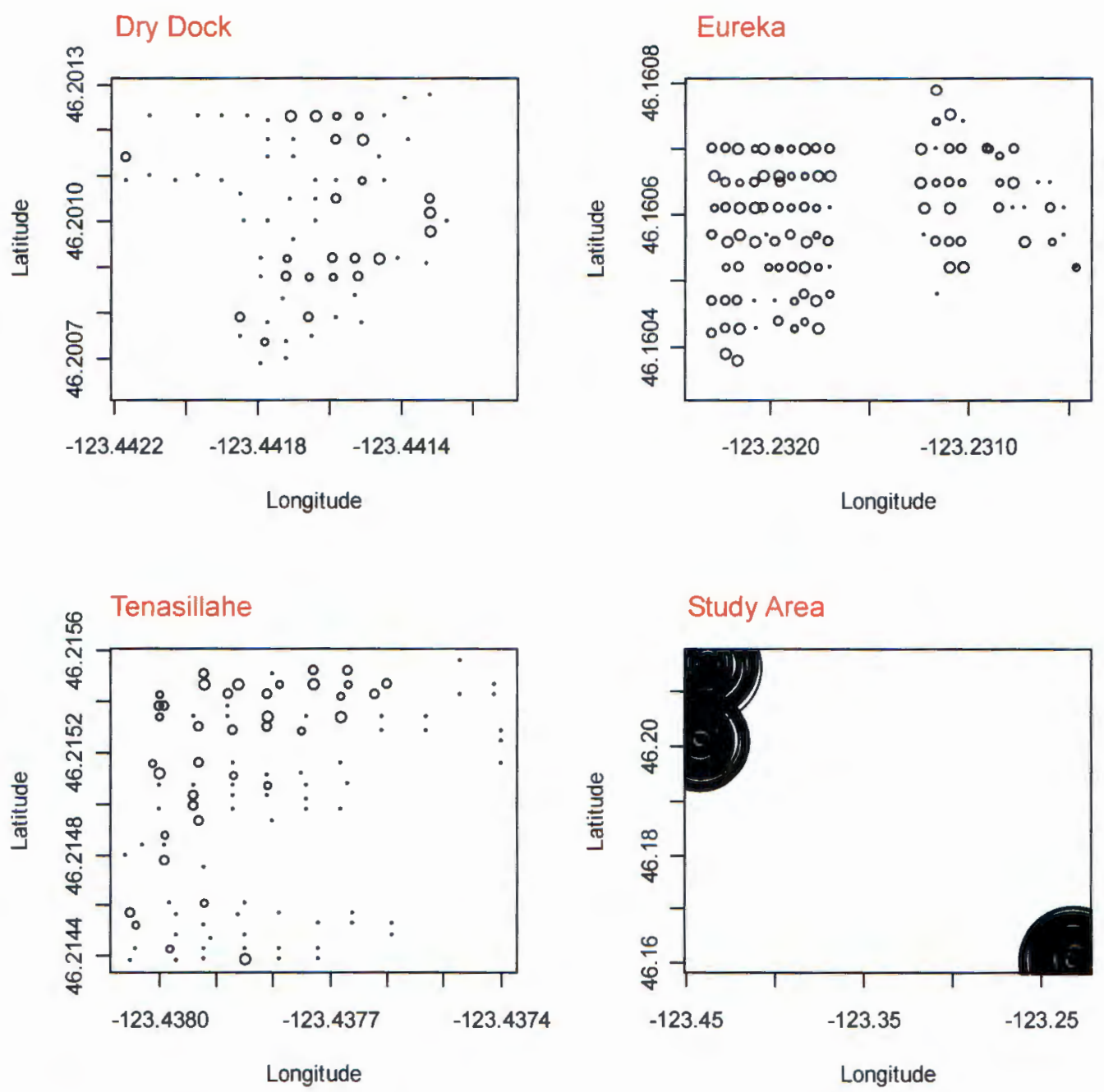

Figure 10. Sampled Galerucella observations plotted against their latitude and longitude: Dry Dock top left, Eureka top right, Tenasillahe bottom left, and study site bottom right. The lack of spatial clumping validates there is no spatial autocorrelation, circles are proportional to number of Galerucella observed. 


\section{Greenhouse Experiment}

During high velocity treatments the beetles were observed climbing down the stem toward the rising water, investigating the water with their antennae, and then climbing back up the stem. This behavior was repeated as the water rose but the behavior was not exhibited during low velocity treatments. Beetles aggregated on the shoot tips as the water continued to rise (Figure 11). The greatest proportion of Galerucella scour occurred at low stem density and high velocity (59\%). The combination of medium stem density and low velocity resulted in the lowest level of scour (27\%) while low and medium stem densities lost almost equal proportions of beetles during the medium velocity treatment ( $50 \%$ and $48 \%$ respectively) (Figure 12 ). The greatest proportion of Galerucella evaded the water during treatments of medium stem density and low velocity, while the greatest proportion that flew occurred at high stem density and low velocity (Figure 13 ). 


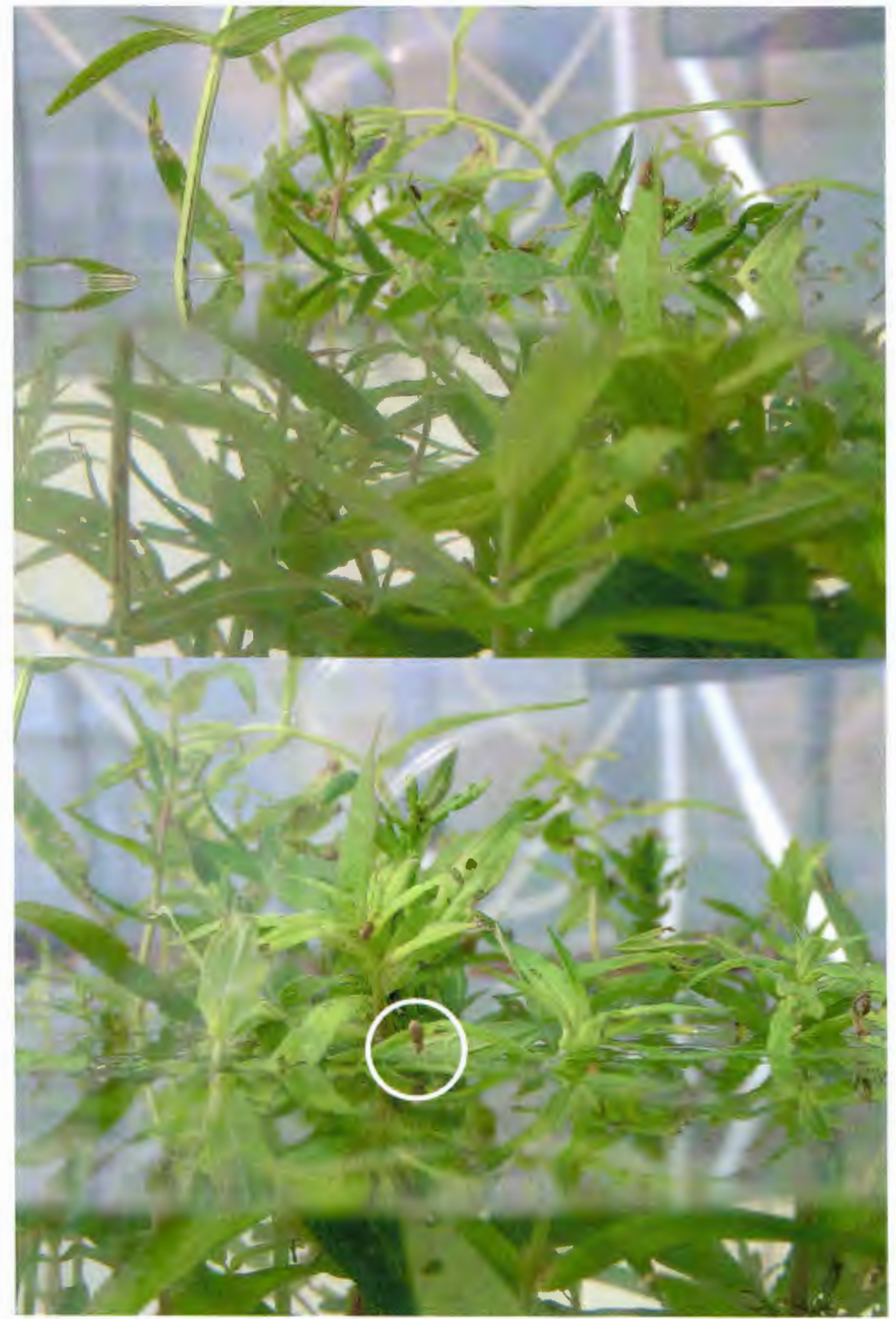

Figure 11. Aggregation of beetles on shoot tips as water continues to rise within experimental apparatus (top). Beetle at the center of the frame is investigating the rising water with its antennae (bottom). 


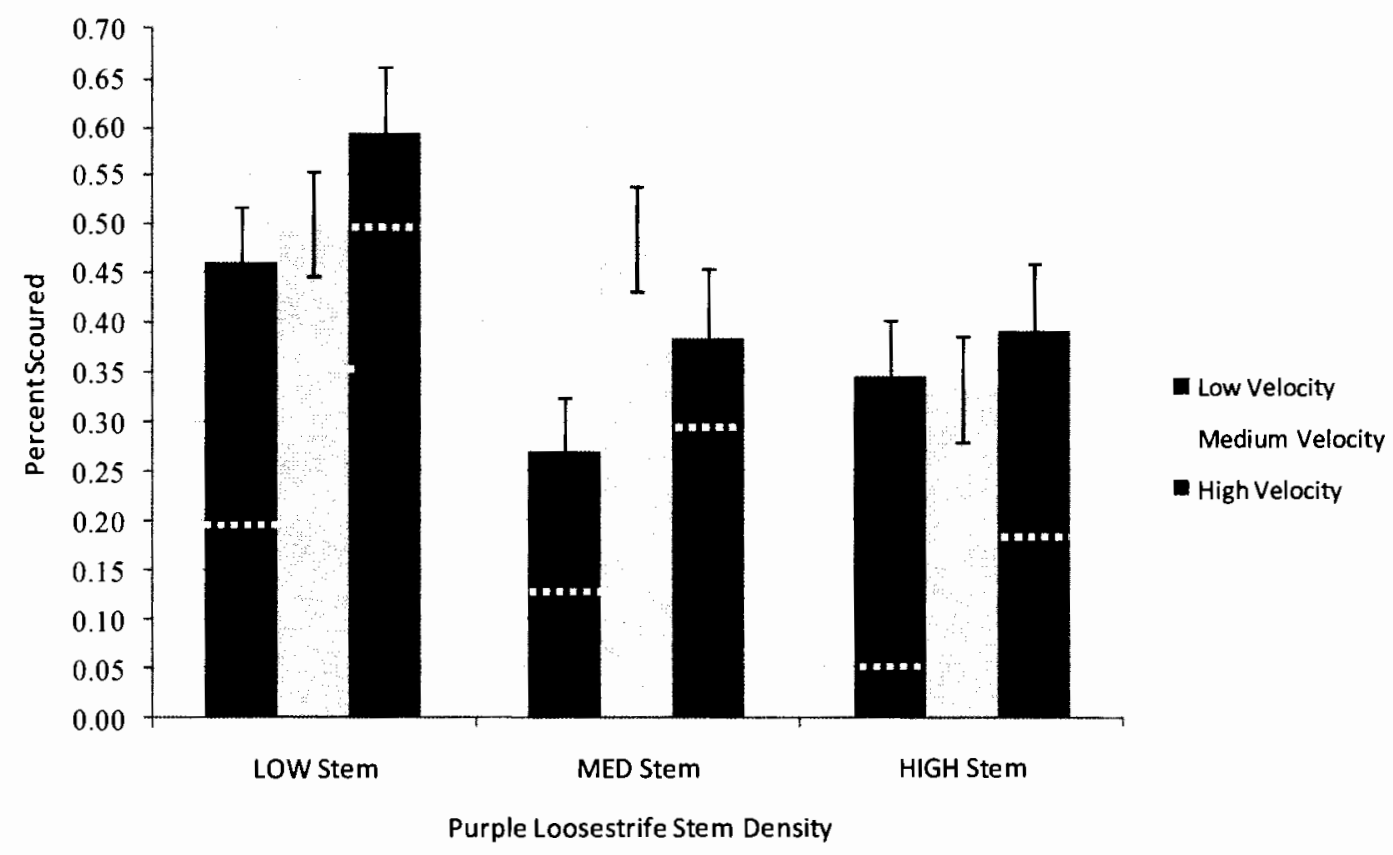

Figure 12. Proportion of Galerucella scoured from the system ( $\pm 1 \mathrm{SE})$ during greenhouse experiment. Dashed white lines represent predicted pattern of Galerucella proportion that would become scoured from system. 


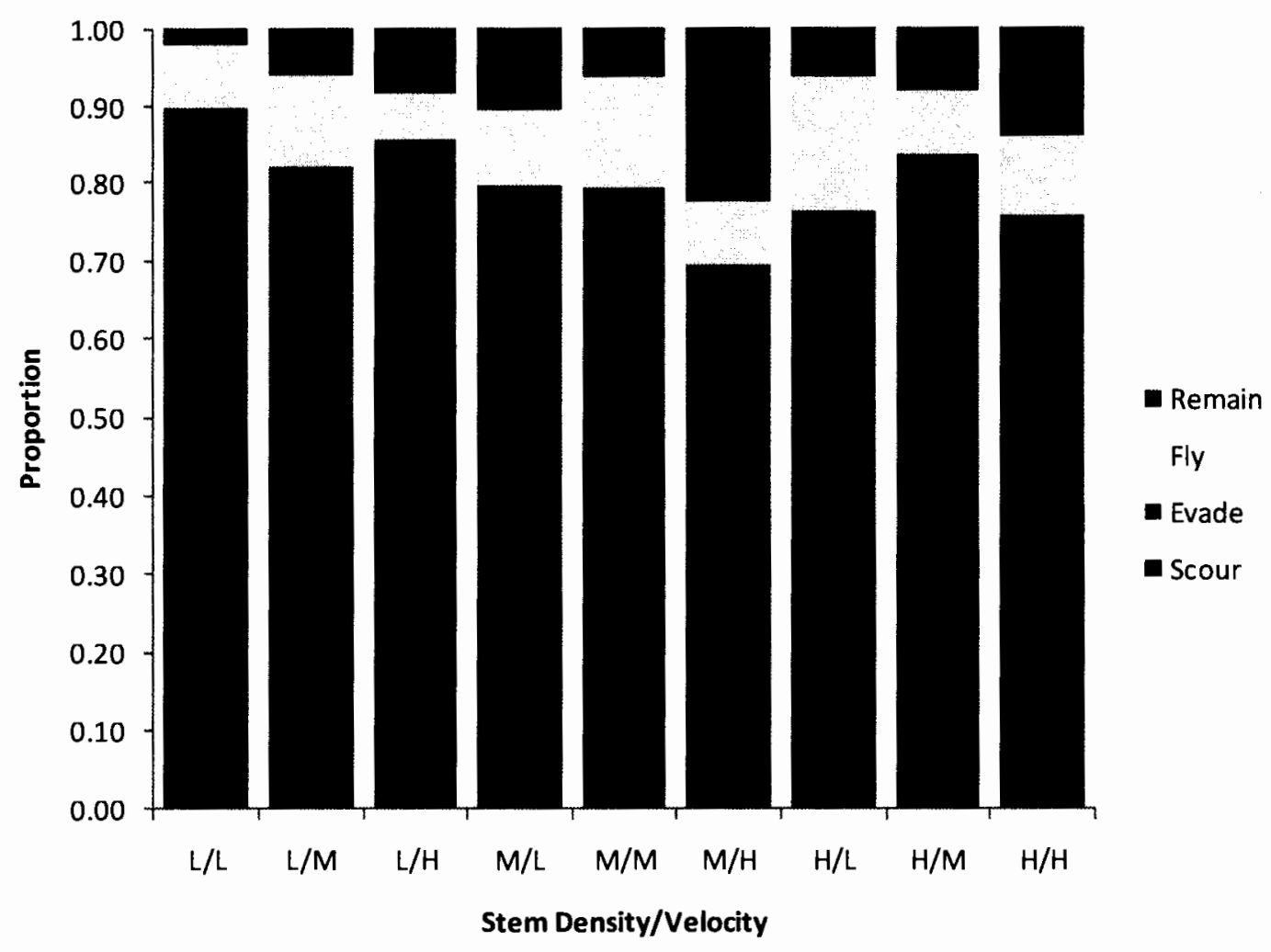

Figure 13. Mean Galerucella response across treatments. "Remain" means to remain submerged under the water's surface for the duration of the treatment; "Fly" means flee the system by flying away; "Evade" means to climb to the tip of a tall stem, thereby evading the water; and "Scour" means to have been pulled off of the stem by the water and scoured from the system. 
Two-way ANOVA showed both stem density and velocity to be significant and no significant block effect (Table 8). An overall downward trend exists with regard to the proportion of Galerucella scoured from the system and stem density (Figure 14). Tukey's HSD test identified that none of the blocks were significantly different, all three stem density treatments were significant, and only the low and high velocity treatments were borderline significant $(\operatorname{adj} . \mathrm{p}=0.06)$.

Table 8. Effects of different factors and their interactions on the number of Galerucella scoured during greenhouse experiment.

\begin{tabular}{llllll}
\hline Effect & df & SS & MS & $F$ & $p$ \\
\hline Block & 4 & 0.375 & 0.094 & 1.023 & 0.409 \\
Stem & 2 & 12.449 & 6.225 & 67.820 & $6.17 \times 10^{-13 * * *}$ \\
Velocity & 2 & 0.649 & 0.325 & 3.535 & $0.04^{*}$ \\
Residuals & 36 & 3.304 & 0.092 & & \\
\hline
\end{tabular}

Significance codes: ${ }^{‘ *}{ }^{\prime} 0.05,{ }^{\prime * * *} 0.001$ 

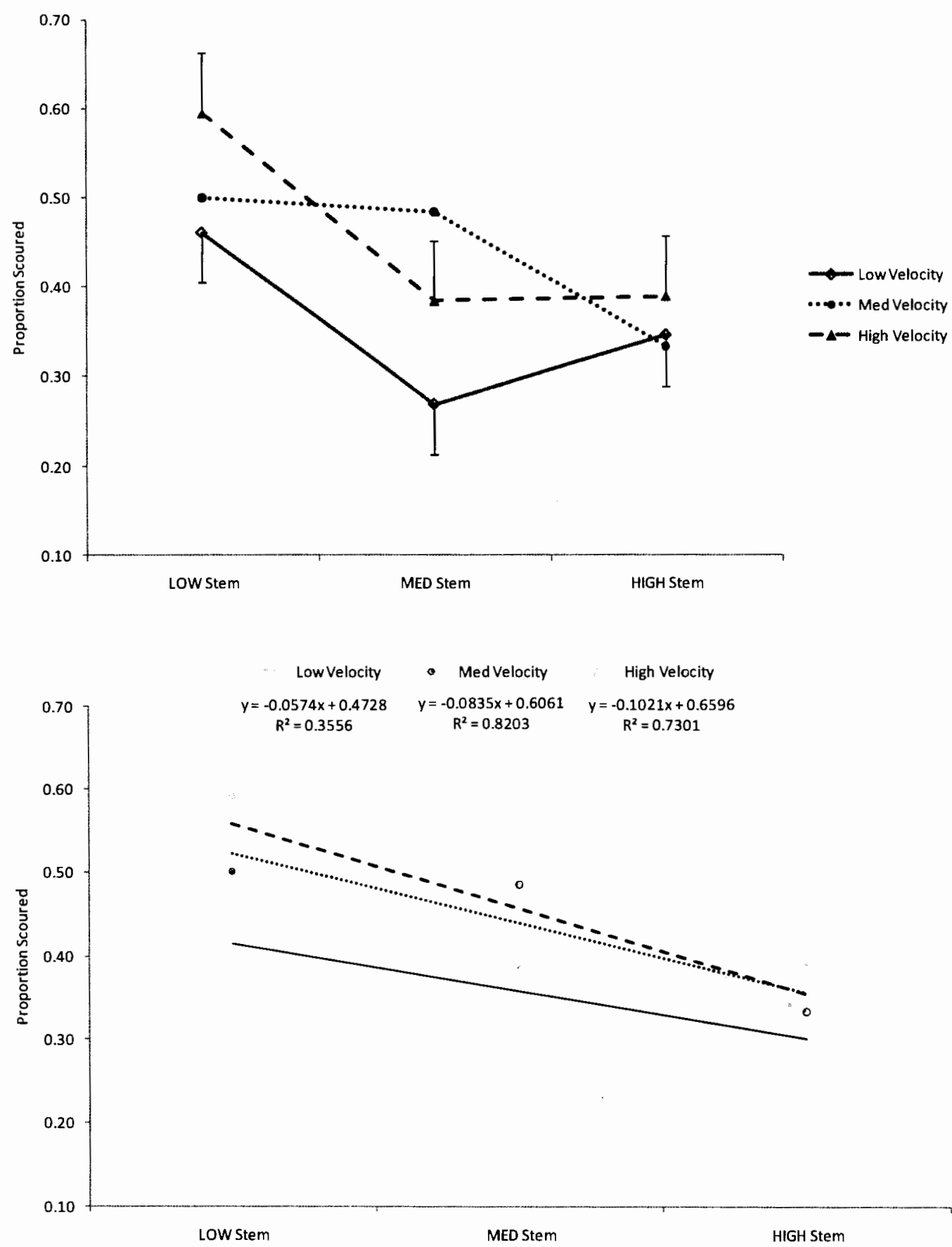

Figure 14. Measure of effect sizes of purple loosestrife stem density and water velocity treatments on proportion of Galerucella scoured from system (top). Trendlines superimposed to show overall downward trend with regard to proportion of Galerucella scoured and stem density (bottom) (Error bars of $\pm 1 \mathrm{SE}$ have been removed for simplicity). Data shown are group means. 


\section{Discussion}

General

Strategies to manage invasive species often involve one of two approaches: 1) the development of black lists to prohibit species known to have detrimental effects or 2) the development of white lists that permit species known to have no detrimental effects. White list approaches have proven to be much more effective in preventing the establishment of non-indigenous species as they require extensive knowledge of the species biology, life history, and potential methods of control (Whittenberg and Cock 2001, Simberloff 2006). For the most part, the United States tends to employ black lists while New Zealand and Australia employ the white lists, although the very practice of biological control exemplifies a white list. Potential biological control agents are rigorously screened to determine whether or not they pose ecological or economical threats and only when determined they do not are they approved for release. Unlike traditional white lists though, which require that species be reevaluated at appropriate intervals to identify host shifts, genetic variations, etc., host specificity of biological control agents is typically only tested during the initial screening process. Even though this study produced no observations of Galerucella on any plant other than purple loosestrife, biological control programs would benefit from periodic review of host specificity in which agents are re-collected from the field and re-evaluated against the target plant and those associated with it at the field site. 


\section{Field Study}

Galerucella observations all fell within the elevation that purple loosestrife occurred. While this might seem trivial, it is an important point considering the insect is released as the biological agent of the plant. This host specificity also accounted, in part, for loosestrife stem density being the key significant predictor of agent presence; explaining almost $81 \%$ of the variability in the data. Elevation has an indirect effect on Galerucella in that it affects where purple loosestrife grows. As previously mentioned, a priori knowledge showed that purple loosestrife did not occur at all elevations at the study sites. Cattails tend to dominate at the lowest elevation and wind scour precludes the growth of purple loosestrife at the highest elevations. For this reason, I sampled an elevation gradient smaller than the actual gradient represented at the sites in order to capture observations of purple loosestrife.

Further inspection of the distribution of presences and absences of the biological control beetle relative to the abundance of purple loosestrife stems showed that above a stem density of approximately $32 / \mathrm{m}^{2}$ the agent was found to be present $100 \%$ of the time. This suggests that density, and not just presence of purple loosestrife, has a positive influence on the probability of observing the biological control agent. The stem density threshold was not applicable in areas of increased disturbance such as inner channels, elevational depressions, etc. Spatial analysis using GIS showed that while densities of purple loosestrife were substantial (20-55 stems $/ \mathrm{m}^{2}$ ) on the east end of the Eureka site, Galerucella occurrences were very low (0-9 individuals). The water velocity at the mouth of this channel was approximately 
$160.9 \mathrm{~cm} / \mathrm{min}$ when measured in the field but the velocity just 16 meters inland was too slow to register on the velocity meter (FP211 Global Water Flow Probe, Global Water Instrumentation, Inc.). The adult beetles were most likely scoured from the stems of the loosestrife plants near the mouth of this channel where water velocity is the greatest, carried on the flowing water, and deposited inland (west end) during the tidal interchange.

Studies investigating the effectiveness of the root-weevil, Hylobius transversovittatus, in areas of high disturbance such as inner channels are strongly encouraged. Larvae of the weevil live in the roots where they can feed for up to two years. During this time the larvae remove vast amounts of plant storage tissue and are protected from the energy of the tidal waters by the structure of the root. It may be that treatments combining Galerucella at higher elevations and Hylobius at lower elevations can overcome the effects of increased disturbance. While Hylobius presence was a measured variable during this study, I did not observe the beetle at any of the three study sites.

The final model, including only purple loosestrife stem density, elevation, and their interaction as predictors of Galerucella presence accurately classified more than $92 \%$ of the 201 presence/absence observations of the test data. Overall performance of models in which the data are highly zero inflated can be misleading because while the model may have a very good overall percent correct classification, the percentage is heavily influenced by the high number of absences in the data (Yangdong Pan, personal communication). In this study it is more important that the model correctly 
classify sites with beetles being present rather than absent. The fact that this model had a very good overall performance and returned only 10 false-positives is important in this regard.

\section{Greenhouse Experiment}

The greenhouse experiment helped explain the field observations that stem density plays a major role in retaining Galerucella at biological control release sites. Both purple loosestrife stem density and water velocity made significant contributions to explaining the variability in the data. I anticipated higher scour to occur at lower stem density treatments and to increase as water velocity increased. Indeed, scour increased with increasing water velocity in the low stem treatments, but not in the medium and high stem treatments.

During high velocity treatments the beetle's behavior indicated they were aware of the rising water, periodically climbing down the stem to investigate it and then moving back up the stem. This behavior was observed much less frequently in the medium velocity treatment and rarely during low velocity. The mechanism that allows beetles to recognize the flowing waters was not investigated with this study. It may be through stem vibration and only detectable beyond a certain velocity. At low velocities the water appeared to catch the beetles off guard; they became submerged with greater frequency but remained under water for a short time because they were pulled off of the stem by the positive buoyancy of the air bubble (plastron) that surrounded their body. This is in contrast to the beetle being pulled from the short 
stems by the moving water of high velocity.

Both stem density and water velocity have an effect on beetle scour. Once dislodged from the stem, the adult beetles floated on the surface of the water, and were pushed through the system by the horizontal water velocity. While the beetles did actively swim (Figure 15), the force of the water usually overpowered their efforts. If while on the water surface the beetle came into contact with a stem, it was able to climb up on it and extricate itself from the water. The beetle would then climb away from the water and up the stem, which resulted in an aggregation of beetles on the loosestrife shoot tips. The increased probability of coming into contact with a stem at higher stem densities resulted in the stem density effect. This mechanism by which stem density affects the proportion of beetles scoured from the system is not represented in the current literature and was unexpected. 


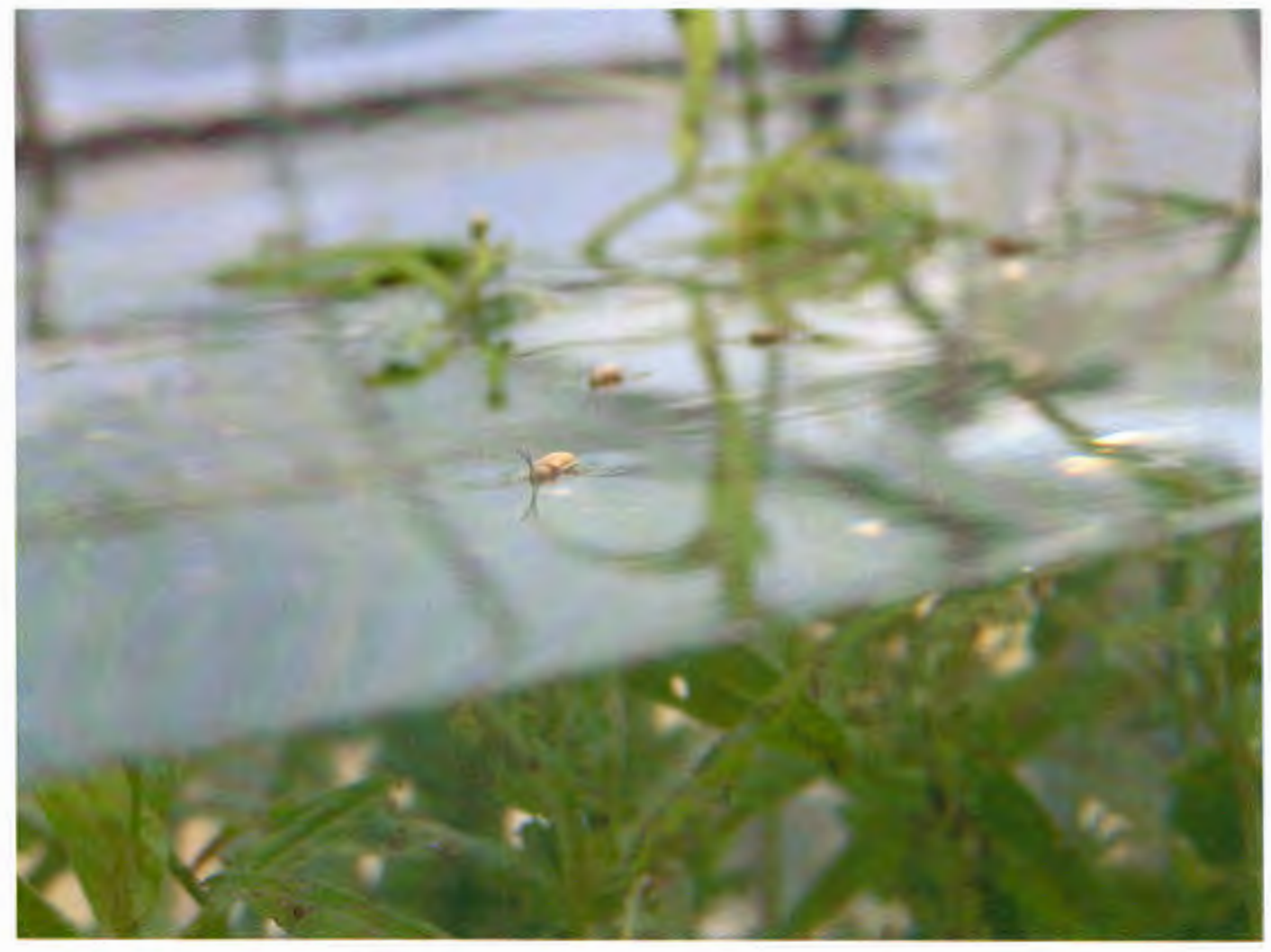

Figure 15. Following being scoured from purple loosestrife stem by rising/flowing waters, Galerucella adults "swim" on water surface tension.

The effects of plant species other than purple loosestrife on the establishment of Galerucella are not yet understood. Would a combined total stem density, including species similar in height to purple loosestrife, have the same effect? Reed canary grass provided the greatest percent cover of all quadrats surveyed at Dry Dock and Tenasillahe and was ranked second overall at Eureka. I have observed previously in the field that Galerucella adults use yellow-flag iris, reed canary grass, and dead purple loosestrife stems to extricate themselves from tidal waters. Reed canary grass can grow to be approximately $2 \mathrm{~m}$ tall, perhaps providing refugia from tidal waters for Galerucella equal to that of purple loosestrife. Greenhouse studies could easily be 
conducted to investigate the effects of plant architecture as well as stem density of species other than purple loosestrife and are strongly encouraged.

The unexpected high proportion of scour that occurred at medium stem density and medium velocity resulted from the combination of the two points described above. The incoming water velocity was not great enough to alert the beetles but was forceful enough to pull them off of the stems. As a result, the beetles were scoured from the stem yet had fewer chances to encounter a different stem in order to extricate themselves from the water. When there is a high stem density the effects of water velocities are lessened, as evidenced by the relative similarity in proportion scoured at the different velocity treatments. In this study I paired vertical and horizontal water velocities (i.e., low-low, medium-medium, and high-high). Future studies investigating all velocity combinations are needed (i.e., low-low, low-medium, lowhigh, etc.) as this will provide a surface from which to predict agent success at all site conditions, including areas of increased disturbance such as inner channels.

The fate of Galerucella beetles once scoured from the system is not clear. The adults are by far the most buoyant life stage of the beetle and the GIS analysis of Eureka shows that if they become dislodged during a flowing-tide they can get pushed further into the site. Conversely, if dislodged during ebb-tides they might float on the water's surface and become redistributed within and among sites. The adult beetles might also fly to evade the waters, or eventually drown. These are important responses that need to be illuminated if we are to improve biological control programs in tidal areas. 
The hypothesis that tidal waters act as vectors of Galerucella was supported through the field work and greenhouse experiment described herein. There was strong support for the hypothesis that the greatest amount of Galerucella scour occurs when stem density is lowest and water velocity is greatest within the low stem density treatment. There was an unexpected increase of scour when both stem density and water velocity were moderate. This was a result of the beetle's lack of awareness of the flowing water, sufficient energy from the water to remove the adults from the stems, and fewer stems for the beetles to encounter upon which to extricate themselves. The hypothesis is rejected at high stem density treatments as velocity had little effect on Galerucella scour.

\section{Management Implications}

Biological control of purple loosestrife in areas of tidal influence is not a lost cause. We previously understood the failure of loosestrife biological control programs in tidal areas to be due to the mechanical removal by tides. While this is true in part, I showed that a stem density effect occurs at densities greater than $32 \mathrm{stems} / \mathrm{m}^{2}$ and that this density determines the degree to which this is true. The augmentation of weed biological control programs with other measures of control is commonly advocated and it is not my intention to imply that control efforts should be abandoned if a site is determined to have insufficient purple loosestrife stem density. In an effort to offset genetic variation in Spartina alterniflora's vulnerability to its biological control agent, Garcia-Rossi et al. (2003) advocated for complimentary control efforts such as 
chemical and/or mechanical strategies to be incorporated into the program in Willapa Bay, Washington. Grevstad et al. (2003) suggested habitat manipulation through fertilization and translocation of large quantities of Prokelisia marginata as additional measurements to improve the same Spartina biological control program. Continued mechanical and herbicidal efforts at sites with insufficient densities of purple loosestrife are encouraged to lessen the available seed source of the plant.

Of specific interest with regard to the program in Willapa Bay, the first biological control program undertaken in a marine intertidal habitat, is the fact that increased winter survival of the planthopper was highly correlated with dead culms $\left(\mathrm{R}^{2}=0.62\right)($ Grevstad 2003). While the majority of Prokelisia marginata nymphs overwinter in the curled leaves retained on dead culms, scour as a result of tidal waters was not investigated in the study. Prokelisia marginata have dimorphic wing development; some are flightless (brachypter), and others possess the ability to fly (macropter). It would be a worthwhile endeavor to investigate if a stem density effect similar to the one identified with this study is occurring in Willapa Bay.

The results of this study showed that with basic pre-release site knowledge including only elevation and mean number of purple loosestrife stems $/ \mathrm{m}^{2}$, managers can predict whether or not the biological control agents that feed on purple loosestrife leaves will be retained on a site in tidal areas. With this new knowledge we can better select future release sites in areas of tidal influence, thereby increasing program efficacy while decreasing propagule pressure and potential host shifts of the nonnative Galerucella. 


\section{References}

Agosta, S. J. 2006. On ecological fitting, plant-insect associations, herbivore host shifts, and host plant selection. Oikos 114(3): 556-564.

Anderson, M. G. 1995. Interactions between Lythrum salicaria and native organisms: A critical review. Environmental Management 19:225-231.

Balciunas, J.K., and E. Coombs. 2004. International code of best practices for classical biological control of weeds. In: Biological Control of Invasive Plants in the US. 1st edition. Corvallis, OR: Oregon State University Press. p.130136.

Bartelt, R. J., Cossé, A. A., Zilkowski, B. W., Weisleder, D., Grode, S. H., Wiedenmann, R. N., and S. L. Post. 2006. Dimethylfuran-Lactone pheromone from males of Galerucella calmariensis and Galerucella pusilla. Journal of Chemical Ecology 32(3): 1-20.

Blossey, B. 1999. Before, during, and after: the need for long-term monitoring in invasive plant species management. Biological Invasions 1:201-311.

Blossey, B., Skinner, L. C., and J. Taylor. 2001. Impact and management of purple loosestrife (Lythrum salicaria) in North America. Biodiversity and Conservation 10: 1787-1807.

Coombs, E. M., McEvoy, P. B., and G. P. Markin. 2004. Tansy Ragwort. Pages 335344 in Coombs, E. M., Clark, J. K., Piper, G. L., and A. F. Confrancesco Jr. (eds). 2004. Biological control of invasive plants in the United States. Oregon State University Press, Corvallis, Oregon USA.

Cunningham, R. B. and D. B. Lindenmayer. 2005. Modeling count data of rare species: some statistical issues. Ecology 86(5): 1135-1142.

Denoth, M. and J. H. Myers. 2005. Variable success of biological control of Lythrum salicaria in British Columbia. Biological Control 32: 269-279.

Diehl J and P. McEvoy. 1990. Impact of the cinnabar moth (Tyria jacobaeae) on Senecio triangularis, a non-target native plant in Oregon. In: Delfosse ES (ed) Proceedings of the VII international symposium on biological control of weeds. Rome, Italy, 1988. Ministry of Agriculture, Forestry, Rome, and CSIRO, Melbourne, pp 119-126

Emery S. L. and Perry J. A. 1996. Decomposition rates and phosphorous concentrations of purple loosestrife (Lythrum salicaria) and cattail (Typha spp.) in fourteen Minnesota wetlands. Hydrobiologia 323: 129-138. 
Fowler, S. V. 2000. Trivial and political reasons for the failure of classical biological control of weeds: A personal view. Proceedings of the X International Symposium on Biological Control of Weeds. 4-14 July 1999, Montana State University, Bozeman, Montana USA. Neal R. Spencer (ed). pp 169-172.

Garcia-Rossi, D., Rank, N., and D. R. Strong. 2003. Potential for self-defeating biological control? Variation in herbivore vulnerability among invasive Spartina genotypes. Ecological Applications 13(6): 1640-1649.

Garbor, T. S., Haagsma, T. and Murkin, H. R. 1996. Wetland plant responses to varying degrees of purple loosestrife removal in southeastern Ontario, Canada. Wetlands 16: 95-98.

Garono, R. J., Thompson, E., and L. Moore. 2007. Assessment of biocontrol agent populations at 15 release sites in the Columbia River Estuary. Submitted to The U. S. Corps of Engineers, Grant: W9127N-06-C-0023.

Garono, R. J., Ferrarese, E., McEvoy, P., Grevstad, F., and S. Schooler. 2008. Assessment of biocontrol agent populations on the Columbia River. Submitted to The U. S. Corps of Engineers, Grant: W9127N-06-C-0023.

Gotelli, N. J. and A. M. Ellison. 2004. A primer of ecological statistics. SinaurAssociates, Inc, Sunderland, Massachusetts USA.

Grevstad, F.S. 1999. Experimental invasions using biological control introductions: the influence of release size on the chance of population establishment. Biological Invasions 1: 313-323.

Grevstad, F. S., and A. L. Herzig. 1997. Quantifying the effects of distance and conspecifics on colonization: experiments and models using the loosestrife leaf beetle, Galerucella calmariensis. Oecologia 110:60-68.

Grevstad, F. S., Switzer, R. W., and M. S. Wecker. 2003. Habitat trade-offs in the summer and winter performance of the planthopper Prokelisia marginata introduced against the intertidal grass Spartina alterniflora in Willapa Bay, Washington. In: Proceedings of the XI International Symposium on Biological Control of Weeds (eds Cullen, J.M., Briese, D.T. Kriticos, D.J., Lonsdale, W.M., Morin, L. and Scott, J.K.), pp. 523-528. CSIRO Entomology, Canberra, Australia.

Grout, J. A., Levins, C. D., and J. S. Richardson, 1997. Decomposition rates of purple loosestrife (Lythrum salicaria) and Lyngbyei's sedge (Carex lyngbyei) in the Fraser River Estuary. Estuaries 20: 96-102. 
Harper, J. L. 1977. Population biology of plants. Academic Press, London UK.

Hitchcock, C. and A. Cronquist. 1973. Flora of the Pacific Northwest. University of Washington Press, Seattle, Washington USA.

Huffaker, C. B. and C.E. Kennett. 1959. A ten-year study of vegetational changes associated with biological control of Klamath weed. Journal of Range Management 12: 69-82.

Janzen, D. H. 1985. On ecological fitting. Oikos 45: 308-310.

Julien, M. H., and M. W. Griffiths (eds.). 1998. Biological control of weeds: A world catalog of agents and their target weeds. CABI Publishing, New York, New York USA.

Lindgren, C. J. 1999. Performance of a biological control agent, Galerucella calmariensis L. (Coleopter: Chrysomelidae) on purple loosestrife Lythrum salicaria L. in sourthern Manitoba (1993-1998). In: Proceedings of the $X$ International Symposium on Biological Control of Weeds (ed N. R. Spencer), pp. 367-382. CSIRO Entomology, Canberra, Australia.

Lockwood, J. L., Cassey, P., and T. Blackburn. 2005. The role of propagule pressure in explaining species invasions. TRENDS in Ecology and Evolution 20(5): 223-228.

Luck, Robert F. 1990. Evaluation of natural enemies for biological control: a behavioral approach. TRENDS in Ecology and Evolution 5(6): 196-199.

Malecki, R. A., Blossey, B., Hight, S. D., D. Schoreder, L. T. Kok, J. Coulson. 1993. Biological control of purple loosestrife. BioScience 43(10): 680-686.

Palmer, J. M. 2007. Biological control of purple loosestrife using Galerucella beetles. M. S. Thesis, University of Michigan.

Pimentel D., Zuniga, R., D. Morrison. 2005. Update on the environmental and economic costs associated with alien-invasive species in the United States. Ecological Economics 52:273-288.

Piper, G. L., Coombs, E. M., Blossey, B., McEvoy, P. B., and S. S. Schooler. 2004. Purple loosestrife. Pages 281-292 in Coombs, E. M., Clark, J. K., Piper, G. L., and A. F. Cofrancesco Jr. (eds.). 2004. Biological control of invasive plants in the United States. Oregon State University Press, Corvallis, Oregon USA. 
Schooler, S. S., McEvoy, P. B., and E. M. Coombs. 2006. Negative per capita effects of purple loosestrife and reed canary grass on plant diversity of wetland communities. Diversity and Distribution 12(4): 351-363.

Schroeder, D. 1983. Biological control of weeds. In: W. E., (ed), Recent Advances in Weed Research. Commonwealth Agricultural Bureau, Farnham pp41-78.

Simberloff, D. 2006. Risk assessments, blackslists, and white lists for introduced species: are predictions good enough to be useful? Agriculture and Resource Economics Review 35(1): 1-10.

Simberloff, D., Parker, I. M., and P. N. Windle. 2005. Introduced species policy, management, and future research needs. Frontiers in Ecology and the Environment 3(1): 12-20.

Simberloff, D. 2009. The role of propagule pressure in biological invasions. The Annual Review of Ecology, Evolution, and Systematics 40: 81-102.

Skinner, L. 1998. Something's bugging purple loosestrife. The Minnesota Conservation Volunteer. Minnesota Department of Natural Resources MarchApril.

Stenberg, J. A., Hambäck, P. A., and L. Ericson. 2008. Herbivore-induced "rent rise" in the host plant may drive a diet breadth enlargement in the tenant. Ecology 89(1): 126-133.

Templer, P., Findley, S., and Wigand, C. 1998. Sediment chemistry associated with native and non-native emergent macrophytes of a Hudson River marsh ecosystem. Wetlands. 18: 70-78.

Thompson, D. Q., Stuckey, R. L., and E. B. Thompson. 1987. Spread, impact, and control of purple loosestrife (Lythrum salicaria) in North American wetlands. Research 2, United States Department of the Interior Fish and Wildlife Service, Washington DC USA.

USDA, NRCS. 2009. The PLANTS Database (http://plants.usda.gov, 23 September 2009). National Plant Data Center, Baton Rouge, LA 70874-4490 USA.

USFWS. 2007. 2007 Waterfowl hunt plan Wallace Island Unit of Julia Butler Hansen Refuge for the Columbian White-tailed Deer. U. S. Department of the Interior Fish and Wildlife Service, Cathlamet, Washington USA. 
Weiher, E., Wisheu, I. C., Keddy, P. A., and Moore, D. R. J. 1996. Establishment, persistence, and management implications of experimental wetland plant communities. Wetlands 16: 208-218.

Wittenberg, R.; Cock, M.J.W. 2001. Invasive alien species. How to address one of the greatest threats to biodiversity: A toolkit of best prevention and management practices. $\mathrm{CAB}$ International, Wallingford, Oxon, UK, $229 \mathrm{pp}$.

Woodward, A., Jenkins, K. J., Schreiner, E. G. 1999. The role of ecological theory in long-term ecological monitoring. Natural Areas Journal 19: 223-233.

Zar, Jerrold H. 1996. Biostatistical analysis. Prentice-Hall, Upper Saddle River, New Jersey USA. 
Appendix A. Specifications and images of greenhouse experimental apparatus

All walls were $0.6 \mathrm{~cm}(1 / 4 \mathrm{in})$ thick with the exception of one end wall of the interior chamber which was $0.95 \mathrm{~cm}(3 / 8 \mathrm{in})$. Through this thicker plate I drilled five rows of eight $0.95 \mathrm{~cm}(3 / 8 \mathrm{in})$ holes and glued into each a $7.6 \mathrm{~cm}(3 \mathrm{in})$ vinyl tube to create laminar flow. In three alternating rows I also drilled seven $1.27 \mathrm{~cm}(1 / 2 \mathrm{in})$ holes to reduce water restriction behind the end wall. This end of the interior chamber was supported to the bottom of the exterior box by $2.54 \mathrm{~cm}(1 \mathrm{in})$ plexiglass legs. The opposite end wall of the interior chamber was framed with $2.54 \mathrm{~cm}(1 \mathrm{in})$ plexiglass to which we glued no-see-um netting with marine grade epoxy. The portion of this end wall that extended from the bottom of the interior chamber to the bottom of the larger box was solid plexiglass. I drilled a $1.27 \mathrm{~cm}(1 / 2$ in $)$ hole into the center of this lower portion and glued a $1.27 \mathrm{~cm}(1 / 2$ in) male plumbing fitting (in horizontal orientation) into the hole. On the other side of this end plate we attached a vinyl hose to the fitting which lead to a submersible pump (GX 2400 from Gen-X). The experimental apparatus used in this study was custom fabricated by Tap Plastics, Inc. in Portland, Oregon. 


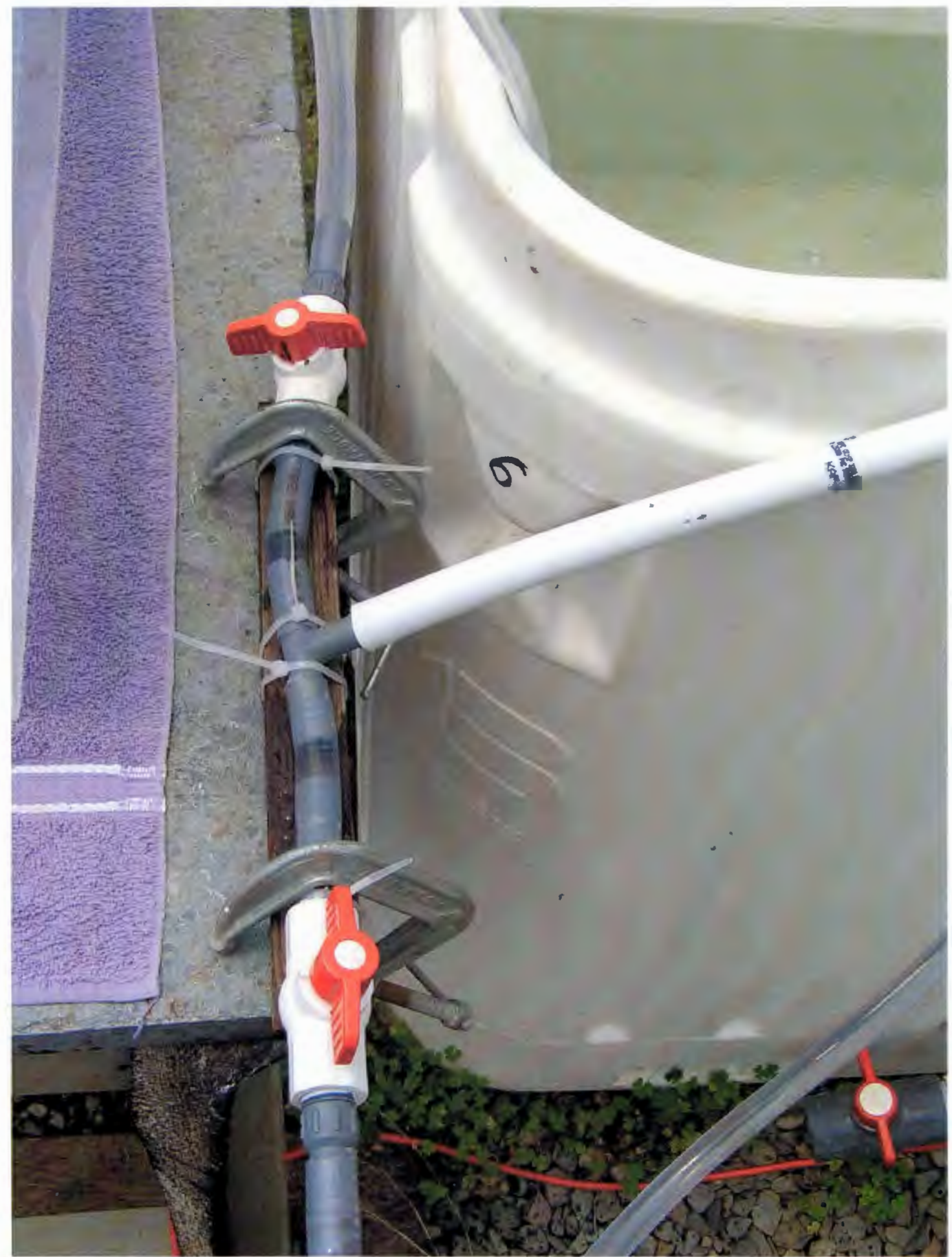

Figure 16. Vertical velocity control; ball valve at bottom diverts water back into large container while ball valve at top diverts water into experimental apparatus. Photo taken from above. 


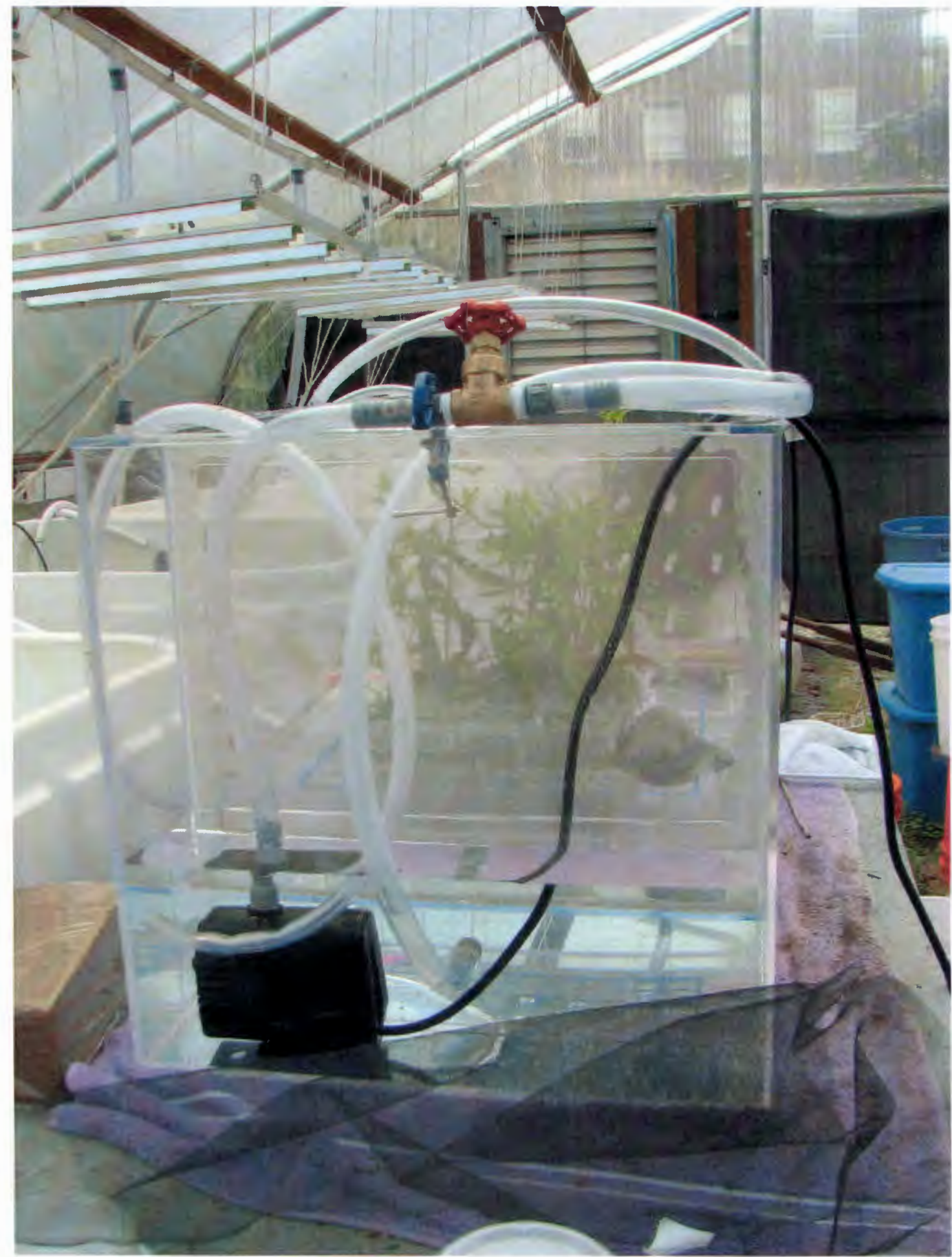

Figure 17. Horizontal velocity control; water is run from submersible pump through gate valve (top) and then through fitting in lower wall plate into the rest of the apparatus. (Photo courtesy of Leslie Bliss-Ketchum) 


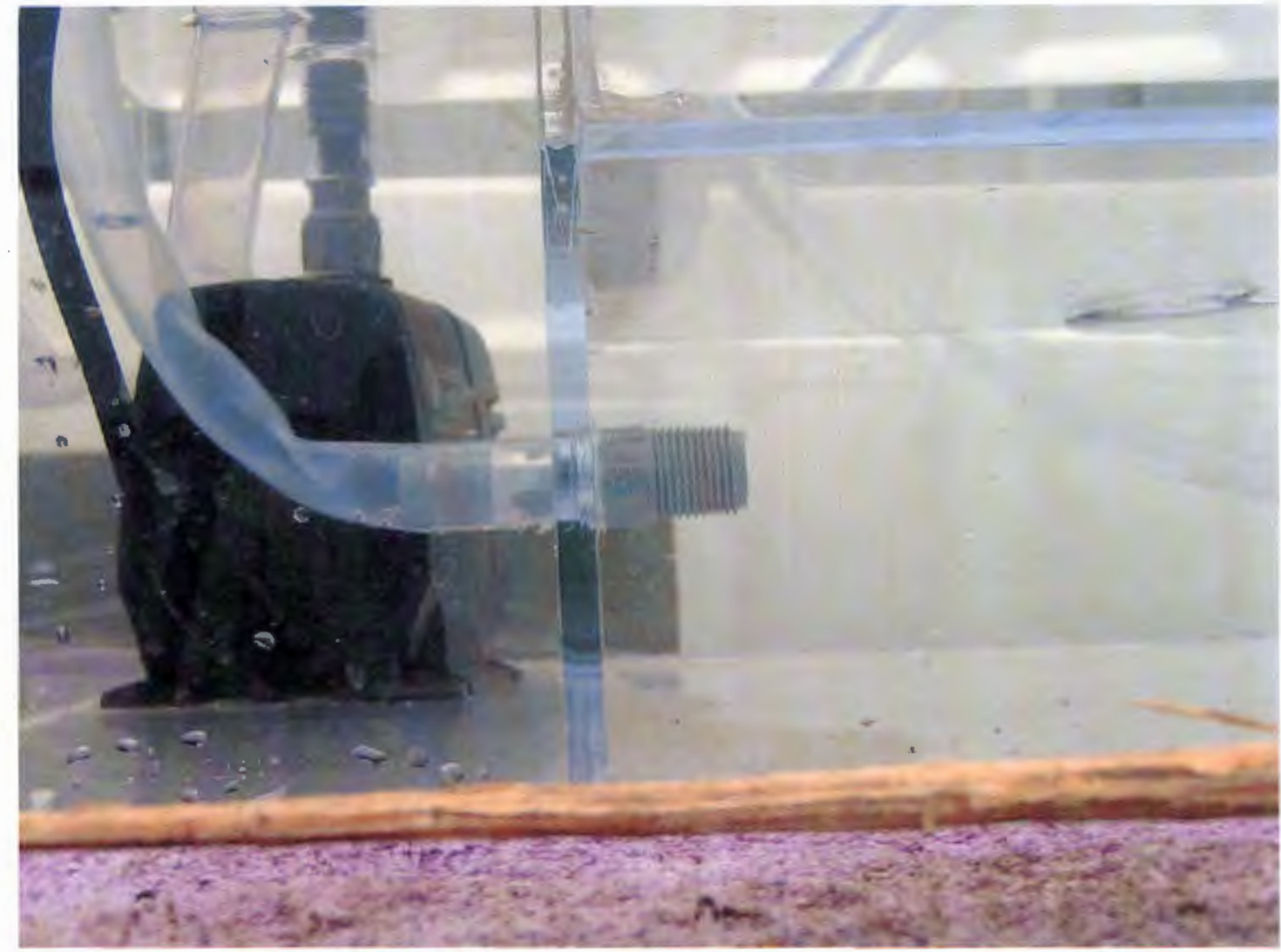

Figure 18. Vinyl tube attached to plumbing fitting in lower portion of end wall. Water is pumped from submerged pump through gate valve, into vinyl tube and through the fitting creating unidirectional flow. 


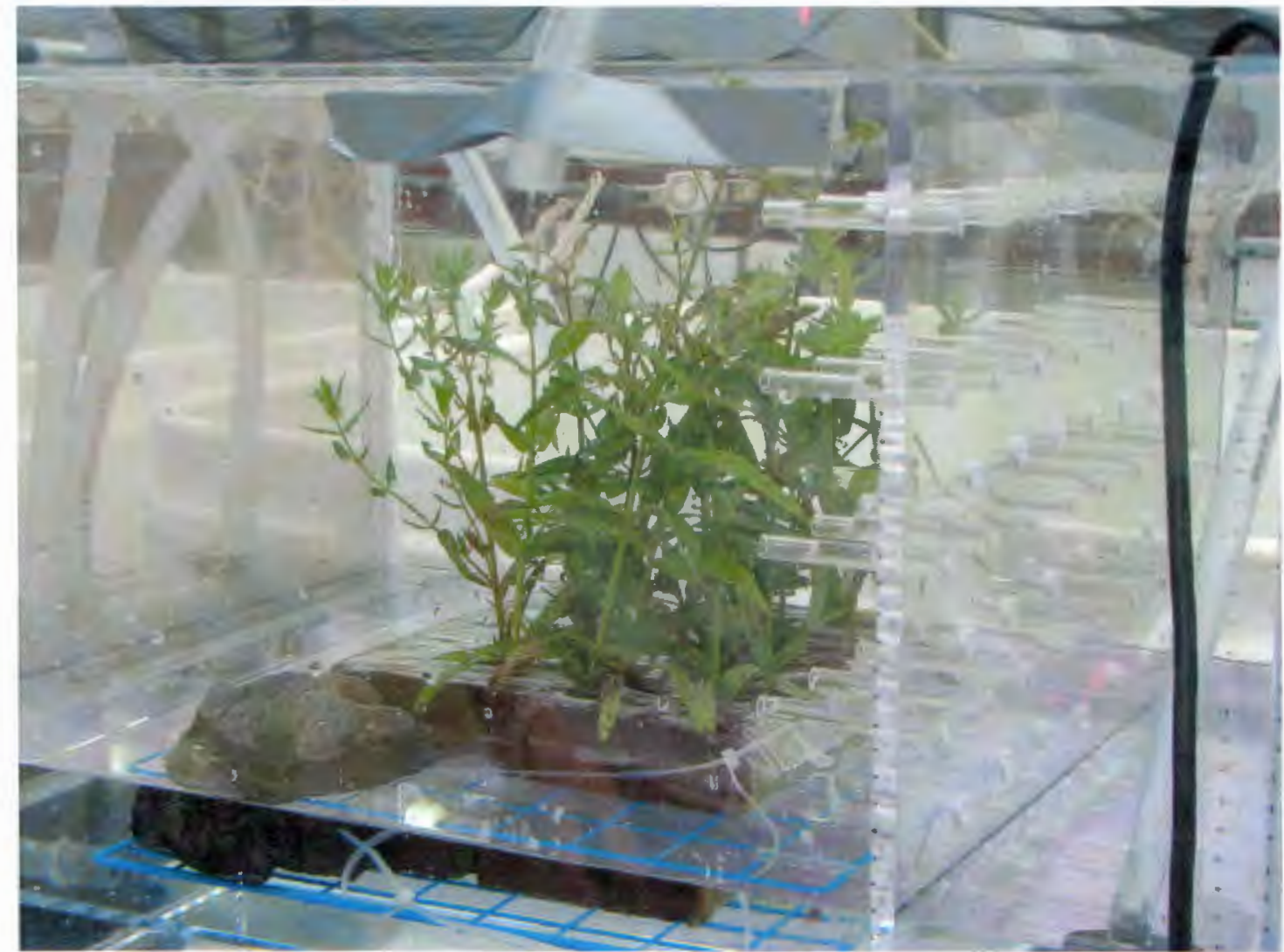

Figure 19. Thick end wall of interior chamber with 5 rows of $8(n=40) 0.95 \mathrm{~cm}(3 / 8$ in) holes with $7.6 \mathrm{~cm}$ ( $3 \mathrm{in}$ ) vinyl tubes glued into each to create laminar flow. Three rows of $7(\mathrm{n}=21) 1.27 \mathrm{~cm}(1 / 2 \mathrm{in})$ holes were also drilled into wall to reduce water restriction. 